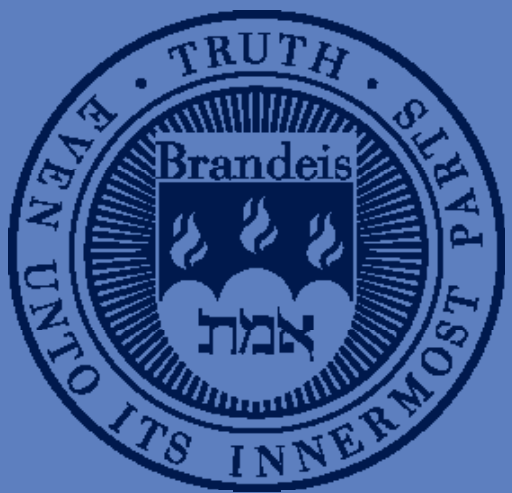

\title{
Fiscal Discriminations in Three Wars
}

George J. Hall, Economics Department, Brandeis University

Thomas J. Sargent, New York University

\section{Working Paper Series}




\title{
Fiscal Discriminations in Three Wars
}

\author{
George J. Hall and Thomas J. Sargent*
}

May 1, 2013

\begin{abstract}
In 1790, a U.S. paper dollar was widely held in disrepute (something shoddy was not 'worth a Continental'). By 1879, a U.S. paper dollar had become 'as good as gold.' These outcomes emerged from how the U.S. federal government financed three wars: the American Revolution, the War of 1812, and the Civil War. In the beginning, the U.S. government discriminated greatly in the returns it paid to different classes of creditors; but that pattern of discrimination diminished over time in ways that eventually rehabilitated the reputation of federal paper money as a store of value.
\end{abstract}

KEY WORDS: REPUDIATION, REPUTATION, DISCRIMINATION, LEGAL TENDER, GREENBacks, Alexander Hamilton, Albert Gallatin, Ulysses S. Grant

\footnotetext{
*Brandeis University and New York University and Hoover Institution; email: ghall@brandeis.edu, thomas.sargent@nyu.edu. This paper was prepared for the April 2013 meeting of the Carnegie-RochesterNYU Conference on Public Policy. We thank the Becker-Friedman Institute of the University of Chicago and the National Science Foundation (SES-0417519) for financial support. The research for this paper was conducted as part of a project on fiscal imbalances sponsored by the Becker-Friedman Institute. We thank Alex Bargar, James Myatt, and Ainie Tan for outstanding research assistance and Andrew Young at the U.S. Department of Treasury Library for helping us track down numerous government documents. We thank our discussant Lee Ohanian for his thought-provoking comments and Rodolfo Manuelli for useful conversations and criticisms.
} 
Inflation is repudiation. Deflation is assumption.

Calvin Coolidge, 1922.

\section{Introduction}

In 1790, the framers of the U.S. federal government debated whether and how to discriminate in the rates of return given to U.S. creditors. James Madison urged the government to allocate payoffs among current and former bond holders in ways that would withhold capital gains from more recent purchasers and compensate former holders who had experienced capital losses from selling their bonds. Alexander Hamilton (1790) opposed Madison's discrimination scheme because of its adverse effects on the expectations of prospective government creditors. Hamilton criticized Madison's proposal, first, because it would defeat Hamilton's goal of fostering a liquid market in U.S. government bonds, and, second, because it would inappropriately reward former holders of government bonds who, by selling, had bet against the credit of the U.S.; it would also unfairly punish current holders who, by buying, had expressed their confidence in U.S. credit.

Hamilton won that argument and Congress did not implement Madison's particular version of a discrimination scheme. ${ }^{1}$ But it did discriminate. In particular, in following Hamilton's advice about restructuring U.S. and state debts in 1790, Congress discriminated among creditor classes in ways that poisoned the U.S. government's reputation for servicing some types of debt (the despised paper money known as 'bills of credit') and that enhanced its reputation for servicing other types of debt (interest bearing medium and long term obligations, especially to foreign creditors).

This paper is about how from 1790 to 1880 the U.S. discriminated among its creditors. U.S. fiscal authorities' propensity to discriminate diminished over time, as revealed in how the United States financed its expenditures during the Revolutionary War, the War of 1812, and the Civil War. During all three wars, the federal government and the states issued debts that differed in their maturities, denominations, and units of account.

\footnotetext{
${ }^{1}$ Although the Congress defeated Madison's proposal for discrimination, a related idea returned to affect the Madison administration two decades later during the War of 1812. Bayley (1882, pp. 52-53) describes the sale in 1814 of a $\$ 25$ million loan that was partitioned into three installments. Under the Treasury's invitation for subscriptions, buyers of the first installment were promised retroactively more favorable terms if subsequent installments garnered lower prices. This was indeed the case, and the Treasury was forced to issue additional shares to buyers of the first installment.
} 
A theoretical contribution of Bryant and Wallace (1984) shapes our understandings about why federal and state governments might want to award different rates of return to different classes of government creditors. Bryant and Wallace showed how such price discrimination can improve fiscal efficiency. The analysis of Fudenberg and Kreps (1987), who studied the mechanics of sustaining different reputations with different parties, also influences our story. The U.S. occasionally tried, with mixed success, to sustain different reputations vis a vis different classes of creditors.

The units of account in which government debts can be expressed and enforced are central to a price-discrimination analysis of monetary and fiscal policy. Bryant and Wallace in effect assumed that a government can issue some securities that are expressed in a foreign government's unit of account or otherwise indexed against domestic inflation, and that it can issue other securities that are not. Whether units of account should be arranged in this way is an issue that underlies a fascinating part of our story, namely, the evolution of U.S. government officials' opinions about whether they should, or even legally could, issue small denomination zero-interest notes (paper money) and whether they should declare those notes legal tender for public and private debts. James Madison thought that making paper money a leading tender was reprehensible, while Ulysses S. Grant thought that it was useful. But making U.S. paper money a legal tender meant something different to James Madison in 1787 or 1813 than it did to Ulysses S. Grant in 1869. In 1787 and 1790, issuing paper money portended depreciation and repudiation. In 1869 and 1870, when the Congress and the President took actions to make U.S. issued paper money as good as gold, paper money meant appreciation and resumption.

The U.S. Constitution prohibits states from issuing bills of credit; during the 1790s federal issues of bills of credit, though not explicitly prohibited, were widely regarded as bad. There was also broad sentiment against making anything other than specie a legal tender. ${ }^{2}$ Madison thought that denying legal tender status to a government issued paper money was a good way to limit its capacity to damage credit markets. ${ }^{3,4}$ Alexander Hamilton's restructuring of federal and states' government debt harshly discriminated against continental bills of credit. That saved federal tax revenues, but by impairing their reputation,

\footnotetext{
${ }^{2}$ See Bancroft (1886) for histories of legal tender acts in colonial America and of the framers' aversion to making paper monies legal tender.

${ }^{3}$ The Madison administration (1809-1817) issued substantial amounts of short term debt during the War of 1812 but did not make it legal tender.

${ }^{4}$ Newcomb (1865) severely criticized the Union's act of making the greenback a legal tender for private debts because of how it redistributed resources among private lenders and debtors. Also see Adams (1891b).
} 
it also had the salutary effect of discouraging future issues of federal bills of credit.

Despite that history, on February 25, 1862 the Union made greenbacks a legal tender for all private debts and some public obligations, an act hotly disputed at the time. In 1869 the Supreme Court declared unconstitutional the act that made greenbacks a legal tender. Soon thereafter President Grant appointed two new justices who concurred in the Court's quick reversal of that earlier decision, thereby affirming that the federal government was empowered to make a paper fiduciary currency a legal tender. Instead of unleashing an era of high inflation fueled by government printing of paper money, President Grant and the Congress presided over a deflation of the greenback price level. That had the effect of awarding people who held greenbacks higher returns than those who, when Union Armies had suffered setbacks, had speculated against the greenback. In 1790, people deplored federal paper money as 'not worth a continental'; after 1879, people trusted greenbacks to be small denomination warehouse certificates for gold. ${ }^{5,6}$ Reputational considerations were very much on the minds of public officials in both periods.

\section{$1.1 \quad$ Imputing theories to decision makers}

Any history of fiscal policies must also be a history of the thoughts of the fiscal authorities. So it is that any historical account of debt management and tax policies has to confront a challenge posed by a group of irrelevance theorems from modern macroeconomics. These theorems assert that for real economic outcomes, choices among different tax, debt management, and monetary policies that finance identical paths of government purchases and transfers are irrelevant. Some of the theorems say that government open market operations and other debt management policies are irrelevant, while others say that the choice between debt and taxes is irrelevant. ${ }^{7}$ To construct our historical account, we

\footnotetext{
${ }^{5}$ At least they were until 1933. The Madison-to-Grant transformation of attitudes and policies toward legal tender bills of credit helped set the stage for the U.S. eventually to become a challenger to the UK's status as managing an international monetary standard. See Silber (2008) for an account of how U.S. Treasury policy at the start of World War I pursued this aim.

${ }^{6}$ This transformation did not occur in a vacuum. The Bank of England suspended convertibility in 1797 but resumed convertibility at par in May 1821. That example of how to run a responsible monetary and fiscal policy was in the air in the mid nineteenth century U.S.. Bank of England notes were not a legal tender during the suspension, a fact cited in the debate over the 1862 legal tender act in the U.S.. See Fetter (1950) and Adams (1891a,b).

${ }^{7}$ See Wallace (1981), Sargent (1987, ch. 6), Peled (1985), Chamley and Polemarchakis (1984), and Barro (1979).
} 
need a theory that breaks such irrelevance theorems. ${ }^{8}$ More precisely, we need to ascribe an irrelevance-breaking theory to the historical figures who made the fiscal decisions that we study.

\section{Ideas and policies}

Ideas about tax smoothing, the possibility and advisability of issuing state-contingent debt, and the wisdom of issuing and making a federally issued paper money a legal tender not convertible into specie all affected U.S. government decisions. The fact that the government faced an intertemporal budget constraint tied ideas about these topics together inextricably.

\subsection{Ideas about tax smoothing}

Hamilton (1790) and the Congress rescheduled Continental and state obligations in ways that they hoped would give the federal government sustained access to domestic and international credit markets. That would expand the Federal government's subsequent options for financing temporary surges in government expenditures by borrowing, thereby allowing it to moderate the contemporary tax increases needed to finance those surges. This part of Federalist policy was embraced and extended by the Jefferson administration when it took office in 1801. In his 1807 report to Congress, Secretary of Treasury Albert Gallatin used a line of reasoning that contains all of the components of a normative model of fiscal policy later formalized in models of Barro (1979) and Aiyagari et al. (2002). Gallatin's report recommended that tax rates should be set to "provide a revenue at least equal to the annual expenses on a peace establishment, the interest on the existing debt, and the interest on the loans which may be raised. ... losses and privations caused by war should not be aggravated by taxes beyond what is strictly necessary." Gallatin (1837, p. 360 ${ }^{9}$ Thus, Gallatin proposed that the best way to pay for a surge in government expenditures would be temporarily to borrow during the surge, to increase taxes permanently by enough to service the resulting debt, and after the expenditure surge had ended, to run a net of interest surplus sufficiently large to roll over the debt. Like Hamilton, Gallatin's presumption was that the debt would surely be serviced as promised, and that a good fiscal policy

\footnotetext{
${ }^{8}$ This is why we take our stories from the friction laden Bryant and Wallace (1984) structure as a way of short-circuiting the Modigliani-Miller logic of Wallace (1981).

${ }^{9}$ Also see Dewey (1912, p. 128).
} 
would adjust net of interest surpluses required to service the debt in order to smooth tax distortions over time.

U.S. fiscal authorities embraced Gallatin's model throughout the nineteenth century. Gallatin and his successors presumed, and wanted markets to presume, that U.S. government debts would always be paid in a timely manner; they promoted expectations that no circumstances would be offered as excuses for failures to pay. Essentially, they proposed to use risk-free government debt to smooth tax distortions across time and they sought to sustain a reputation that their debt would be risk-free. They would smooth tax distortions across states only to the extent that resort to risk-free debt allowed them effectively to 'self-insure' government finances. For our story, it is important to note that they did not purposefully set out to avail themselves of the type of explicit insurance arrangement provided by state-contingent debt, or implicit insurance via state-dependent inflation, that is envisioned in a tradition that follows Lucas and Stokey (1983).

\subsection{What about Lucas and Stokey (1983)?}

In representative agent Ramsey models of Lucas and Stokey (1983) and Chari et al. (1994), a government optimally finances a stochastic stream of exogenous government expenditures by trading state-contingent claims with the private sector. The government thereby enters into a complete risk-sharing scheme with the private sector that allows it to smooth tax distortions across time and across random histories of government expenditures. Lucas and Stokey (1983) and Chari et al. (1994) show that if the government does not have access to complete insurance markets but can issue only risk-free nominal bonds, then it can achieve the same equilibrium outcomes by using history-contingent inflation and deflation to award real capital losses and gains to holders of government bonds. Here, denominating risk-free bonds in a nominal unit of account, then making nominal values respond appropriately to random shocks to government expenditures, are parts of an optimal fiscal and monetary policy. Sims (2001) used this logic to argue against 'dollarization' schemes because they prevent sovereign governments from reaping the benefits that flow from using inflation to award history-contingent returns to government creditors.

But early American policy makers did not see it Sims's way. ${ }^{10}$ Influenced by the repu-

\footnotetext{
${ }^{10}$ The case set out by Lucas and Stokey (1983) for having explicitly state contingent government debt depends on their assumption that government expenditures are exogenous. Things change when having access to expenditure insurance has adverse incentive effects on those who choose government expenditures, as in the settings of Sleet (2004) and Sleet and Yeltekin (2006). In other settings, such adverse effects substantially alter incentive feasible allocations and the history-contingent debt contracts that support
} 
diation of the Continentals, they saw inflation as abrogating contracts, not implementing a well understood risk-sharing scheme between the government and the private sector. For more than eighty years after 1790, most American statesmen denied that there were benefits to be reaped by denominating government debt contracts, and forcing citizens to denominate theirs, in a nominal unit of account other than specie. This drove their hostility to making a Federal paper money a legal tender.

\subsection{Opposition to state-contingent government debt}

Throughout the nineteenth century, the preponderance of official U.S. opinion was that it was not a good idea to use inflation to award history-contingent returns on government securities. But the extent to which policy makers associated legal tender notes with 'repudiation' evolved substantially. At first, the anti-inflation preference was tightly linked to opposition to making paper money a legal tender. But eventually, that link was broken because the stigma attached to legal tender paper monies had vanished. Before we describe how that happened, it is important to consider the role in early U.S. fiscal history played by another aspect of those Ramsey plans.

\subsection{The optimality of a one-time repudiation}

Representative agent Ramsey models, both those in the complete markets tradition of Lucas and Stokey (1983), Lucas (1986), Chari et al. (1994), and Jones et al. (1997), and those in the incomplete markets tradition of Aiyagari et al. (2002), prescribe large scale sovereign debt defaults and capital levies at time 0, coupled with enduring commitments never again to default or expropriate wealth. If we regard 1789 or 1790 as 'time 0', then the framers of the U.S. Constitution aimed to do something like that when they presided over a substantial discrimination against and virtual repudiation of a substantial portion of debt that the U.S. had used to finance the Revolution, while then immediately seeking to sustain expectations that the Federal government would not do that again. One way

they tried to generate those expectations was by poisoning the reputation of the type of government debt that they had repudiated most, namely, paper money.

them. See Atkeson (1991), Phelan and Townsend (1991), and Thomas and Worrall (1990). 


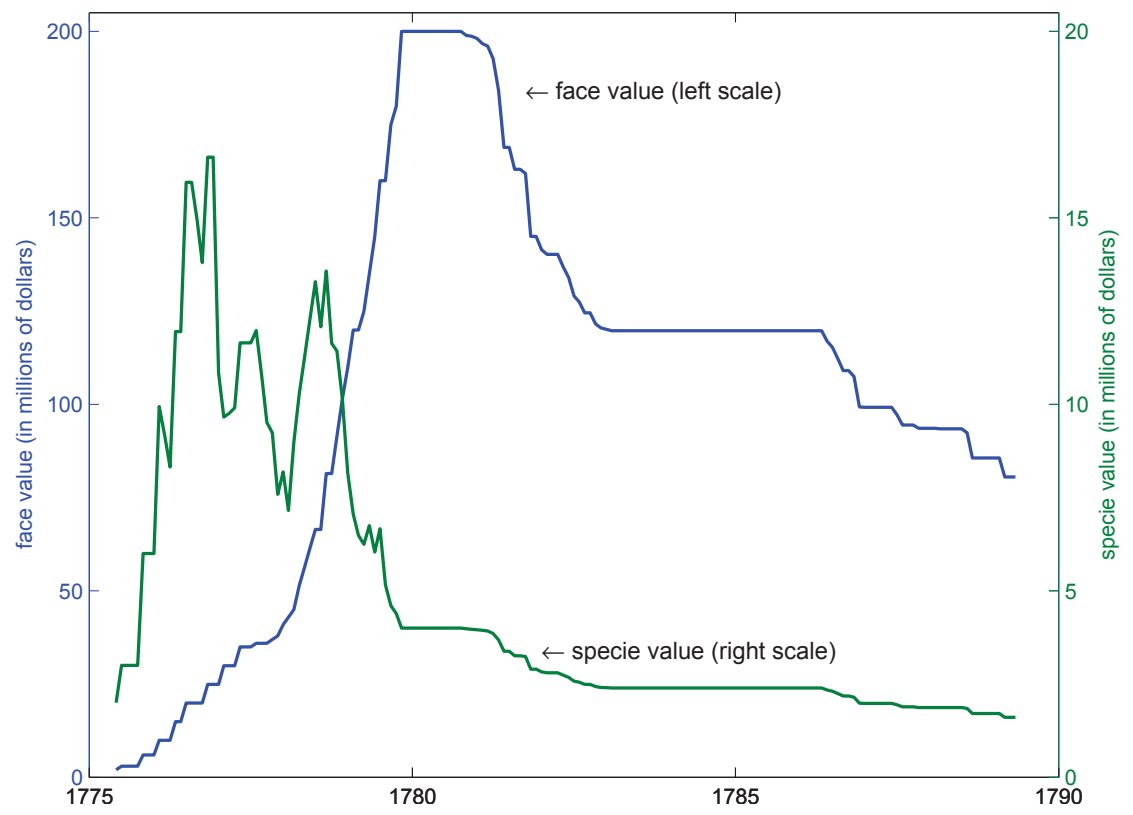

Figure 1: Face and Specie Value of the Outstanding Continental Dollars

Source: The face value is from Grubb (2011); the specie value is computed using the price level from Bullock (1895, p. 135).

\section{A reputation poisoned}

Thirteen states and the Continental Congress financed the American revolution by issuing interest bearing debts and paper monies. Paper monies were known euphemistically as 'bills of credit'. ${ }^{11}$ The Continental Congress issued so much non-interest bearing paper money that it depreciated markedly vis a vis the prevailing unit of account, the Spanish dollar, a silver coin. See figure 1. The Continental Congress first issued bills of credit on June 22, 1775. Into early 1776, these bills were accepted and traded near their face value. But during 1776, emissions occurred faster than the states redeemed and returned them via state taxes, so that by December there was nearly $\$ 25,000,000$ in circulation and the paper currency had lost $1 / 3$ of its value. By November 1779, the total nominal amount outstanding was $\$ 199,990,000$ and 50 Continental dollars purchased 1 Spanish dollar. In March 1780, the Continental Congress threw in the towel, recognized the depreciation of Continental dollars, and accepted 40 Continental dollars in place of 1 Spanish dollar in remittances.

The Continental dollar continued to be traded during the 1780s. Purchasers hoped that

\footnotetext{
${ }^{11}$ For a related discussion, see Sargent (2006).
} 


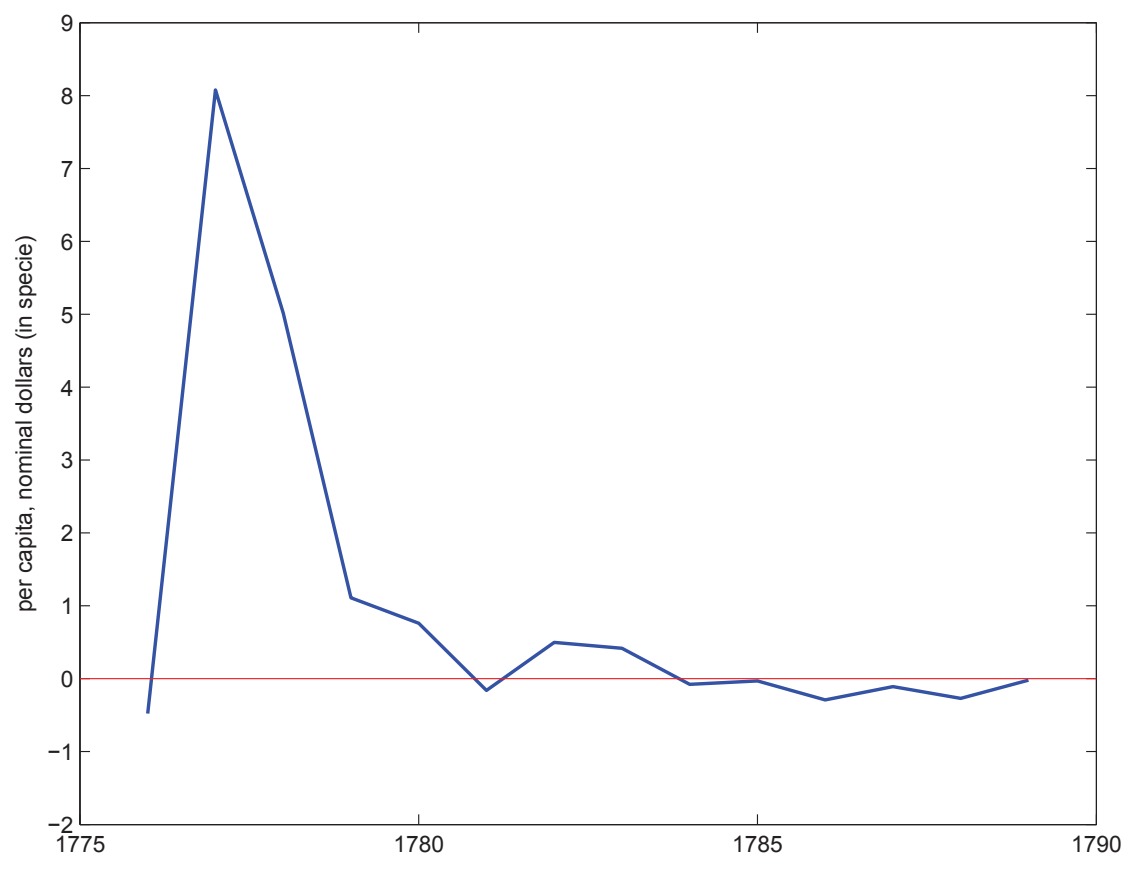

Figure 2: Per Capita Continental Government Primary Deficit

Source: Authors' calculations.

the government would raise sufficient revenue, perhaps through the sale of Western lands, to redeem these bills at or near par. ${ }^{12}$

Although they were never declared legal tender, seignorage from Continental bills of credit yielded nearly $\$ 40$ million dollars of specie and accounted for $84 \%$ of all Continental revenue between 1775 and 1781 . The remaining $16 \%$ came primarily from requisitions from the states and gifts from abroad. The Continental government raised about $\$ 47$ million in Spanish dollars via taxes and seigniorage over these 7 years, while it spent nearly $\$ 85$ million net of interest payments and accrued about $\$ 41$ million in specie-denominated debt and interest in arrears. ${ }^{13}$ Most expenditures were for the war, but the newly formed government also spent over $\$ 10$ million establishing government entities such as the Post Office, making payments to the Native Indian population, and financing diplomatic ventures. ${ }^{14}$

By 1782, with its ability to print money exhausted and hamstrung in its ability to tax

\footnotetext{
${ }^{12}$ For example, see Francis White's advertisement on page 3 of the August 12, 1786 issue of the Pennsylvania Packet. For further discussion of the Continental Dollar during the 1780s and 1790s, see Grubb (2008).

${ }^{13}$ About $\$ 18$ million of this debt was in the form of certificates of indebtedness, an I.O.U. issued by Army quartermasters as payment for supplies and services. These certificates were not recorded in the Continental accounts until 1783 when they were exchanged for final settlement certificates.

${ }^{14}$ For further details on the sources and calculations behind these figures, see Hall and Sargent (2012).
} 
under the Articles of Confederation, the Continental Congress's revenues plummeted. The Continental Congress was unable to raise sufficient revenue to pay the interest payments on its debt, much less any promised principal payments. In 1784, it owed $\$ 2$ million in promised interest payments (not including those in arrears), but received only $\$ 723,000$ in revenue. As illustrated in figure 2, unable to borrow any further, the government set spending equal to revenue, deferring nearly all interest payments. Hence, figure 2 does not reveal the Gallatin-Barro tax smoothing pattern that we will observe later in figure 10 for the Louisiana Purchase and the War of 1812 and figure 12 for the Union during the Civil War. ${ }^{15}$ Over the next seven years, the interest-bearing debt grew to $\$ 53$ million largely through the accumulation of interest payments in arrears.

Throughout the 1780s, repayment of the Revolutionary debt remained in doubt, as indicated by its being traded at about 20 percent of its face value. The domestic debt was divided between explicit loans from the Continental government, known as the loan office certificates, and the final settlement certificates, which represented promises to civilians and soldiers to redeem unpaid bills and wages. Ferguson (1961, p. 252) argues that the loan office certificates were the "best part of the debt" and consistently traded at higher prices than the final settlement certificates. Most speculative trade occurred in final settlement certificates, particularly those issued to Revolutionary soldiers and officers who typically sold their securities soon after receiving them. As we will see below, Hamilton ultimately treated owners of loan office certificates and final settlement certificates equally.

\subsection{Hamilton haircuts}

Following the recommendations of Hamilton (1790), the Funding Act of August 4, 1790 authorized the newly created Treasury to issue three new loans: a consol, known as the $6 \%$ stock, that paid a $6 \%$ coupon; a consol, known as the $3 \%$ stock, that paid a $3 \%$ coupon; and a consol, known at the deferred $6 \%$ stock, that paid a $6 \%$ coupon but with interest payments deferred until 1801. For every $\$ 100$ in face value of domestic Continental debt (i.e., the loan office certificates and final settlement certificates) redeemed, creditors received $\$ 66.67$ in the $6 \%$ percent stock and $\$ 33.33$ in the deferred six percent stock. Indents of interest (i.e. interest payments in arrears) were exchanged for the 3 per cent stock at par. The Federal government assumed the States' debts. Owners of state debts received 4/9 in the 6 percent stock; $2 / 9$ in the deferred six percent stock; and $3 / 9$ in the 3 per cent stock. To compute the

\footnotetext{
${ }^{15}$ In those two figures, temporary positive surges in the net-of-interest deficit are followed by a string of small or moderate net-of-interest surpluses, as prescribed by Gallatin.
} 
amount owed to a state creditor, the government added the principal and the accumulated unpaid coupon payments. Relative to par values, Hamilton's rescheduling administered substantial haircuts to domestic creditors; ${ }^{16}$ but relative to the heavy discounts on U.S. bonds that prevailed in the mid 1780s, Hamilton and the Congress treated bond holders well, especially relative to how they treated owners of Continental dollars, who were offered one dollar in specie for every 100 Continental dollars exchanged.

With the assumption of the State debts bringing the face value of the debt to $\$ 74.3$ million in species (about 35 percent of GDP), the refinancing of the domestic debt into the three new bonds began in September 1790. ${ }^{17}$ As illustrated in figure 3, Continental loans and the associated interest in arrears comprised about 55\% of the government's obligations. The share in State debt was 25\%. Principal and unpaid interest owed to foreigners comprised 19\%, with the outstanding Continental currency, now valued at one cent on the dollar, making up the final $1 \%$.

Grubb (2008) estimated that the face value of the Continental dollars outstanding and unredeemed in 1789 was $\$ 80,527,630$. See figure 1 . Had Hamilton and the Congress decided to redeem these bills at face value, the Federal would have doubled. Senator Woodbury, the former Secretary of the Treasury, reported that about $\$ 6$ million of the Continental bills of credit were ultimately redeemed under this Act. ${ }^{18}$ Thus, about $\$ 74$ million of the bills were never redeemed in the forlorn hope that they would ultimately be honored at a better ratio than 1 to 100 .

As shown in figures 4 and 5, the market value of the outstanding rose in anticipation of the refunding. Despite these large capital gains to government creditors, the new bonds they received had market values well below par. Sylla et al. (2006) report that on December $31,1790, \$ 100$ in face value of the $6 \%$ stock traded in Philadelphia for $\$ 90$ and the deferred $6 \%$ and the $3 \%$ stock both traded for $\$ 45$ per $\$ 100$ in face value. Hence owners of existing Revolutionary debt received substantial haircuts, and much of the debt was effectively written off.

The differential treatment across classes of creditors was considerable. An owner of a loan office certificate with a $\$ 100$ face value received assets that on December 31, 1790 were

\footnotetext{
${ }^{16}$ Garber (1991) provides a more complete description of the 1790 refunding. He reckoned that the French received 80 cents on the dollar and the Dutch were paid in full. He did not say what the Spanish received.

${ }^{17}$ Hamilton (1790) computes the total outstanding debt (domestic plus foreign but not including Continental dollars) on January 1, 1790 to be $\$ 52.8$ million. Adding $\$ 18.2$ million of state debts yields $\$ 71.0$ million. Our figure also includes the outstanding Continental dollars and some additional accrued interest.

${ }^{18}$ See item 4. in Elliot (1845, p. 12).
} 


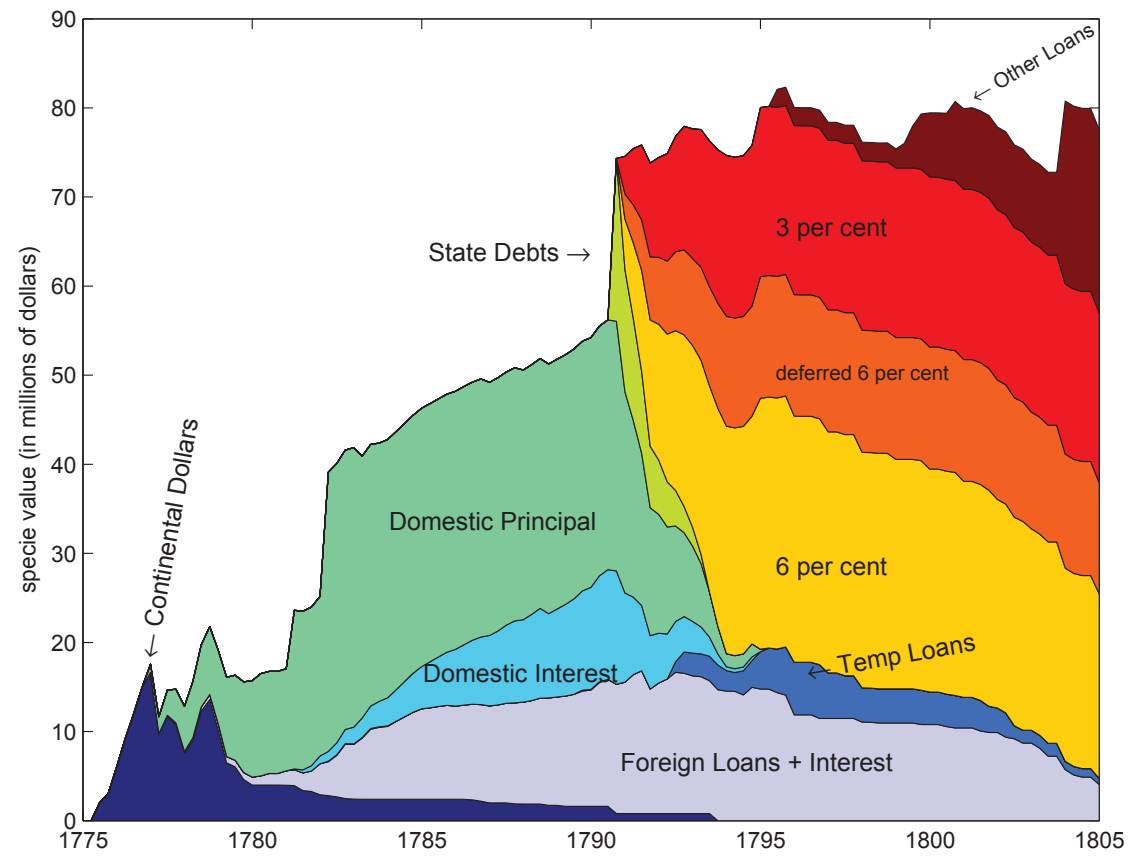

Figure 3: Federal Debt by Type Loan

Source: Calculated using data from Bayley (1882).

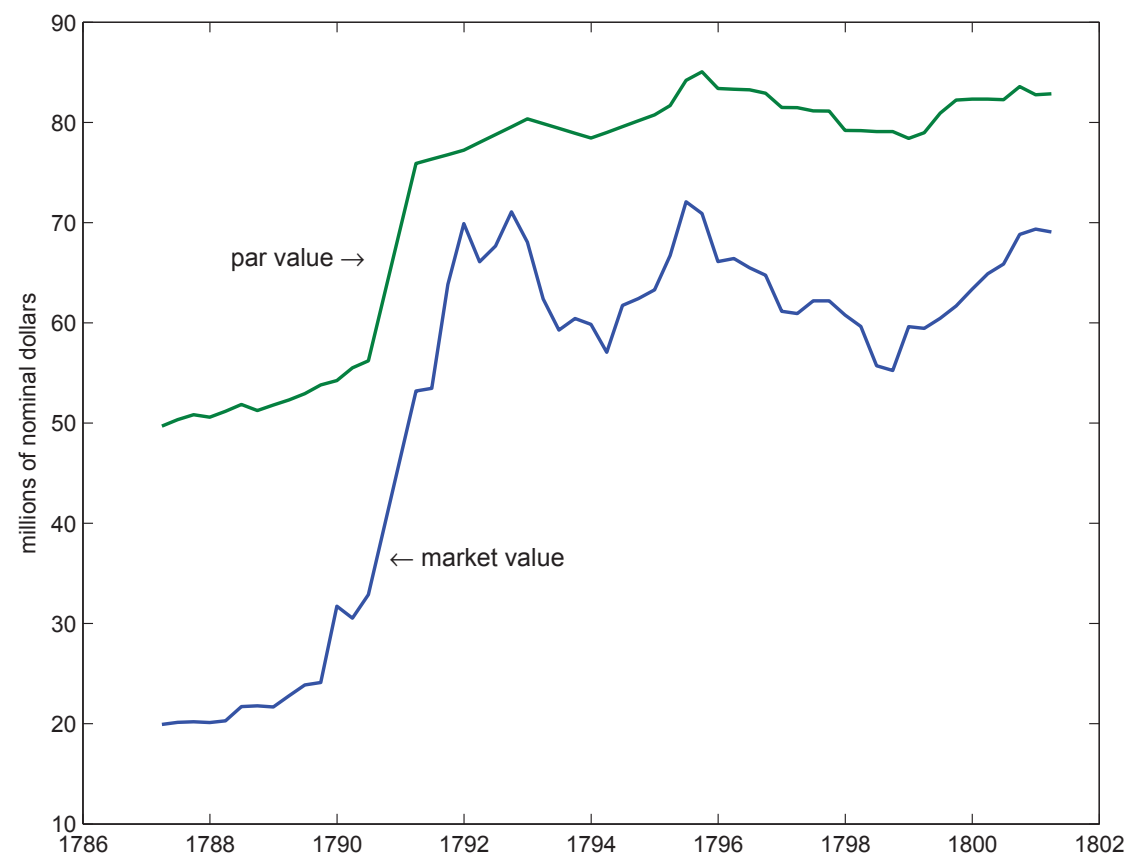

Figure 4: Quantity of the Federal Debt: Principal Outstanding and Market Value 


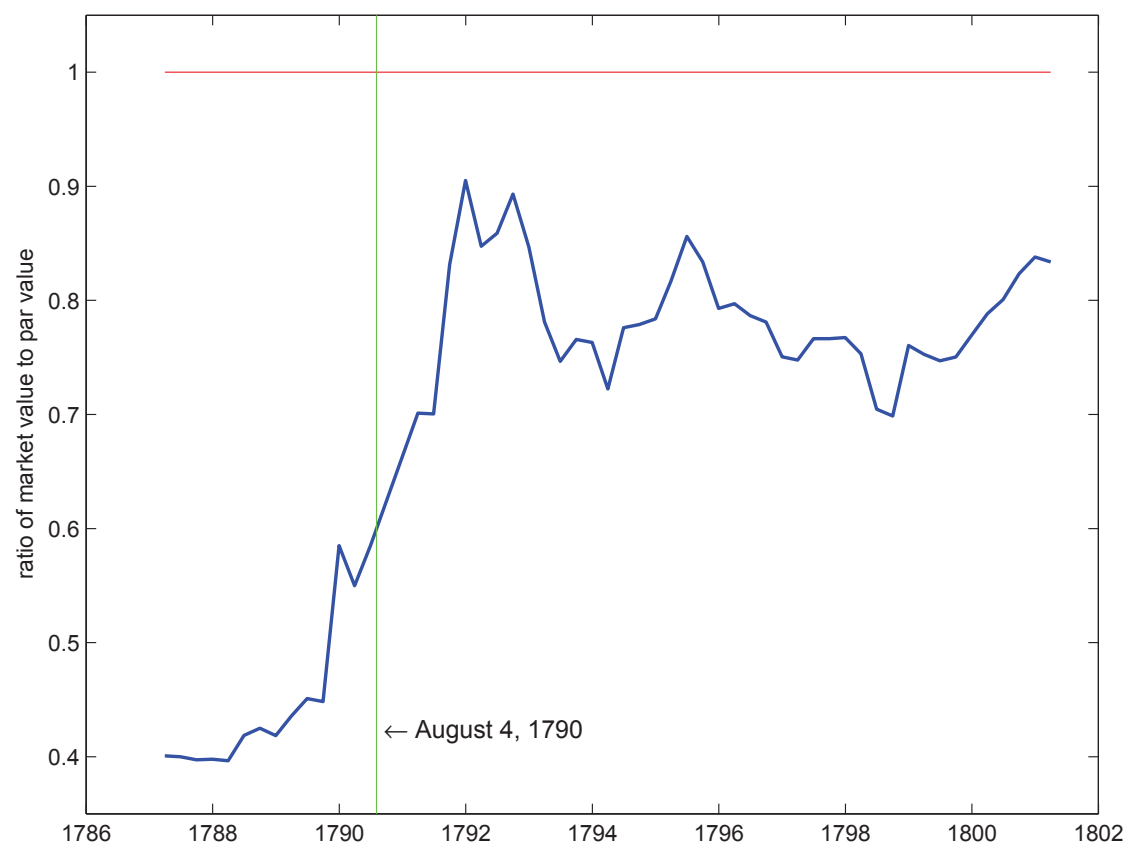

Figure 5: Ratio of the Market Value to the Par Value of the Outstanding Debt

worth $\$ 75$ in specie. In contrast, the bearer of $\$ 100$ in unpaid Continental interest received assets worth only $\$ 45$. State creditors received less for their principal but more than did Continental creditors owning indents for unpaid interest. See table 1.

\begin{tabular}{lc} 
Continental Loan & Market Value of Exchanged Assets \\
\hline loan office certificate & $\$ 75.00$ \\
state debt (principal or interest) & $\$ 65.00$ \\
interest in arrears & $\$ 45.00$ \\
Continental dollars & $\$ 1.00$
\end{tabular}

Table 1: Market Value of Exchanged Assets for $\$ 100$ of Face Value of a Continental Security Authors' calculations using Philadelphia prices on December 31, 1790 from Sylla et al. (2006). 


\subsection{The framers' hatred of paper money}

The framers of the U.S. Constitution wanted to prevent the U.S. and the states from issuing and repudiating a currency again. Thus, Article I, Section 10 of the U.S. Constitution says ${ }^{19}$

No State shall enter into any Treaty, Alliance, or Confederation; grant Letters of Marque and Reprisal; coin Money; emit Bills of Credit; make any Thing but gold and silver Coin a Tender in Payment of Debts; pass any Bill of Attainder, ex post facto Law, or Law impairing the Obligation of Contracts, or grant any Title of Nobility.

Instead, Article 1 Section 8 of the U.S. Constitution gives Congress the power

To coin Money, regulate the Value thereof, and of foreign Coin, and fix the Standard of Weights and Measures;

An earlier draft of the Constitution had actually given the Congress substantially more authority than that, including the right to issue bills of credit. On the morning of August 16,1787 , the eighth clause of the seventh article in the draft of the constitution said that "The legislature of the United States shall have the power to borrow money and emit bills on the credit of the United States." Madison's notes of the convention's proceedings on August 16,1787 record a debate about a motion to strike out the clause authorizing congress to emit bills of credit, excerpts that impress us for their sophistication in (1) stressing the ex ante advantages in terms of promoting credit to be reaped by denying future government decision makers the authority to take actions that ex post would occasionally tempt them (James Wilson); ${ }^{20}$ appreciating advantages of reserving for future decision makers the flexibility to deal with unforeseeable contingencies (George Mason and Edmund Randolph); and arguing that the most damaging effects from issuing a Federal paper money would be prevented if the government could not make it legal tender (James Madison). ${ }^{21}$

\footnotetext{
${ }^{19}$ But in January 1837, in Briscoe v. Bank of Kentucky, the majority of the U.S. Supreme Court, with newly appointed Chief Justice Taney joining, said that state chartered and state owned banks have the right to issue paper money in the form of bank notes. See Howe (2007, ch. 11). Application of the real bills reasoning of Tobin (1961) or the Modigliani-Miller reasoning of Wallace (1981) indicates how this decision undermined the Article I, section 10 prohibition against states' issuing bills of credit. The decision allowed state banks to purchase state bonds with their bank notes.

${ }^{20}$ See Kydland and Prescott (1977).

${ }^{21}$ Dewey (1912, pp. 67-68) discusses and cites the entire debate of August 16, including contributions we have omitted.
} 
Mr. Govr. MORRIS moved to strike out "and emit bills on the credit of the U. States" - If the United States had credit such bills would be unnecessary: if they had not, unjust \& useless.

Mr. MADISON, will it not be sufficient to prohibit the making them a [legal] tender? This will remove the temptation to emit them with unjust views. And promissory notes in that shape may in some emergencies be best.

Mr. Govr. MORRIS. striking out the words will leave room still for notes of a responsible minister which will do all the good without the mischief. The Monied interest will oppose the plan of Government, if paper emissions be not prohibited.

Col. MASON had doubts on the subject. Congs. he thought would not have the power unless it were expressed. Though he had a mortal hatred to paper money, yet as he could not foresee all emergences, he was unwilling to tie the hands of the Legislature. He observed that the late war could not have been carried on, had such a prohibition existed.

Mr. ELSEWORTH thought this a favorable moment to shut and bar the door against paper money. The mischiefs of the various experiments which had been made, were now fresh in the public mind and had excited the disgust of all the respectable part of America. By withholding the power from the new Governt. more friends of influence would be gained to it than by almost any thing else. Paper money can in no case be necessary. Give the Government credit, and other resources will offer. The power may do harm, never good.

Mr. RANDOLPH, notwithstanding his antipathy to paper money, could not agree to strike out the words, as he could not foresee all the occasions which might arise.

Mr. WILSON. It will have a most salutary influence on the credit of the U. States to remove the possibility of paper money. This expedient can never succeed whilst its mischiefs are remembered, and as long as it can be resorted to, it will be a bar to other resources.

Mr. MASON was still averse to tying the hands of the Legislature altogether. If there was no example in Europe as just remarked, it might be observed on the other side, that there was none in which the Government was restrained on 
this head. ${ }^{22}$

The motion to strike out carried 9 states to 2, but the Convention did not go further and impose an explicit prohibition. Thus, the framers opted for silence instead of explicitly prohibiting the federal government from issuing bills of credit. Nevertheless, during the first three quarters of the nineteenth century, it was widely believed that the framers had intended to shut the door on making a paper money a legal tender, and that the fact that they did not go further and explicitly prohibit the federal government from issuing bills of credit simply reflected the constitutional convention delegates' presumption that powers not explicitly awarded should be understood to be denied to Congress. His extensive review of the documentary record convinced Bancroft (1886) that the framers intended that Congress not be permitted to make a paper currency a legal tender:

The refusal of the convention to confer on the legislature of the United States the power to emit bills of credit or irredeemable paper money in any form is so complete that according to all rules by which public documents are interpreted, it should not be treated as questionable; George Bancroft (1886, p. 43).

To strengthen his point, Bancroft cited rousing statements from Washington, Madison, and many others deploring the evils that flow when government makes a paper currency a legal tender. To represent the consensus of opinion before the civil war, Bancroft quoted Daniel Webster:

Most unquestionably there is no legal tender, and there can be no legal tender, in this country, under the authority of this government or any other but gold and silver, either the coinage of our own mints or foreign coins, at rates regulated by congress. This is a constitutional principle, perfectly plain, and of the very highest importance. The states are expressly prohibited from making anything but gold and silver a tender in payment of debts; and although no such express prohibition is applied to congress, yet as congress has no power granted to it in this respect, but to coin money and to regulate the value of foreign coins, it clearly has no power to substitute paper, or anything else, for coin as a tender in payment of debts and in discharge of contracts. Extract from a speech delivered by Daniel Webster in the Senate of the United States on the 21st of December 1836 on the subject of the Specie Circular, quoted by Bancroft (1886, p. 93)

\footnotetext{
${ }^{22}$ We have added italics.
} 
Bancroft's review of the historical evidence was prompted by his disapproval of the Supreme Court's 1884 decision in Juilliard v Greenman, which uphold the Union's making greenback a legal tender during the civil war. ${ }^{23}$ But by 1884, outcomes of decisions of President Ulysses S. Grant and the post-Civil War Republican Congresses had removed the stigma that Madison and his colleagues had cast against Federal legal tender paper money. We describe how this happened in the next sections.

\section{A recuperating reputation}

Despite Gallatin's 1807 tax-smoothing proposal, the Federal government was woefully unprepared financially and militarily to go to war with England in June of 1812. Gallatin's dismantling of the machinery for collecting internal revenue in the early 1800s and the collapse of customs revenue meant the Federal government would have no choice but rely primarily on borrowing to finance the war.

In the three years encompassing March 1812 to February 1815 the Congress authorized five long-term loans with a total face value of $\$ 66$ million. See figure 6. Resistance to the war mainly in the Northeast and the inability to demonstrate a credible revenue stream to back these loans forced the Treasury to sell these bonds at deep discounts. Bayley (1882) reports that the two major loans authorized in 1813 both sold at a $12 \%$ discount, and during 1814 the government sold its debt at a 20\% discount. ${ }^{24}$ Further, these discounts overstate the true revenue raised by these loans since the government accepted bank notes at face value, whose market value themselves were much less than par, as payment for these loans.

Creditors who had lent money to the Federal government in early months of the war watched the value of their loans plummet in late 1814 as Federal bonds traded around $\$ 75$ per $\$ 100$ of face value only to rebound in 1815 after the war's end to trade near par. See figure 7 and compare it to figure 5 for the Federalist period, when market values remained below par values. In 1814, an investor holding a representative portfolio of federal securities lost $13.5 \%$ in real terms. But that same investor received real holding period returns of

\footnotetext{
${ }^{23}$ The court reasoned that because Congress had the power to pay debts, it could do so by any means not expressly prohibited by the constitution; and that little attention needed to be paid to the debates and votes at the constitutional convention because it was difficult to glean a consensus from them; that Congress's power to borrow money included the power to issue obligations in any appropriate form, including handto-hand currency; and that the authority to issue legal tender notes accompanied the right of coinage. (see Dewey (1912, p. 366-67))

${ }^{24}$ Recall footnote 1.
} 


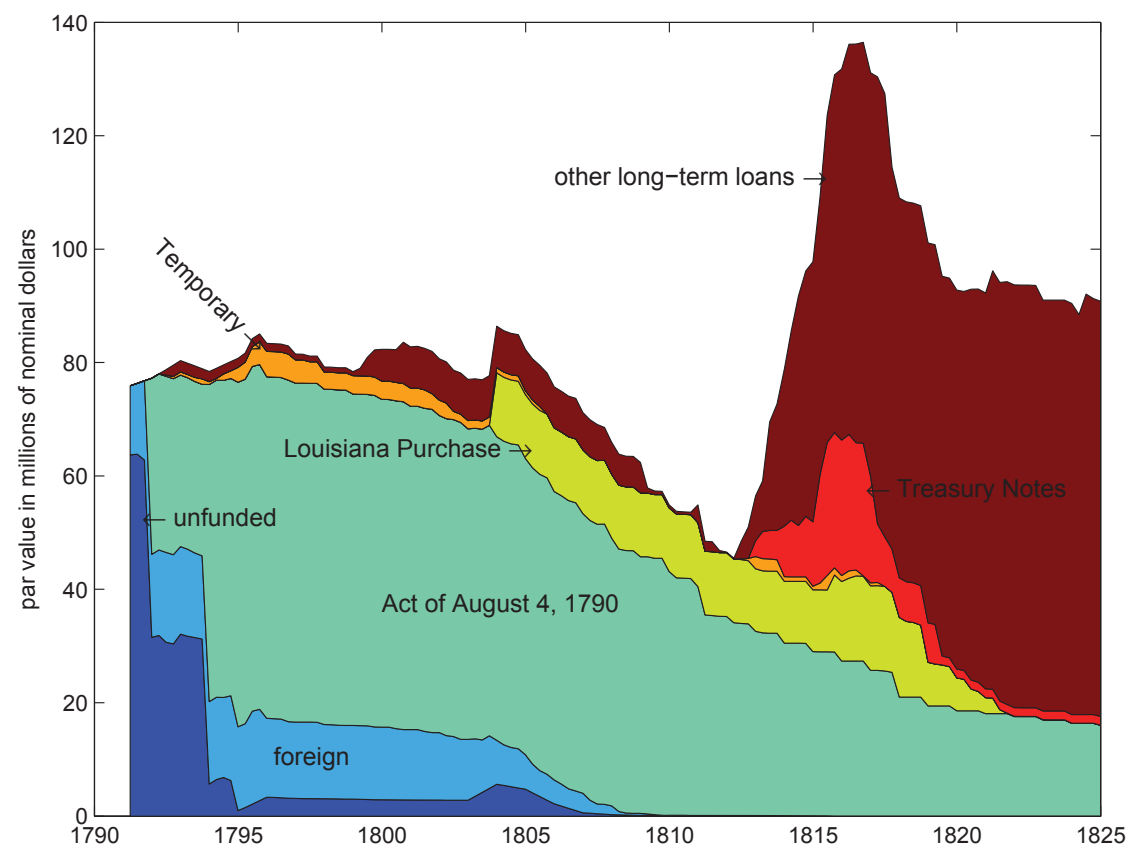

Figure 6: Federal Debt by Type of Loan

Source: Calculated using data from Bayley (1882).

$45.1 \%, 20.7 \%$ and $20.9 \%$ in 1815,1816 and 1817 respectively. See figure 8.

These high bond returns imply high borrowing costs for the Federal government. To see this another way, consider that on January 1, 1812 the Federal government had $\$ 46.6$ million in debt and a $\$ 3.5$ million dollar balance in the Treasury leaving it a net debt of $\$ 43.1$ million. On December 31, 1815 the government's debt was $\$ 75.6$ million higher at $\$ 118.7$ million. However over these four years, the government ran total primary deficits of only $\$ 51.9$ million. This suggests bondholders received returns of $\$ 23.7$ million during this period. Including 1816 into the calculation, the government ran a primary surplus of $\$ 24.3$ million; however the net position of the government fell by only 9.6 million implying that bondholders received the remaining 14.7 million. Computed this way, over these five years U.S. creditors received $\$ 38.4$ in returns, or $58 \%$ of the new debt from the government.

Because the Treasury struggled to secure both a stable revenue stream and sufficient long-term borrowing, it had to resort to short-term borrowing as well. Since the charter of the Bank of the United States had been allowed to lapse in 1811, the Treasury found itself unable get short-term loans from that source as it had earlier. Therefore between June 1812 and February 1815, the Congress authorized five Treasury note issues. These notes 


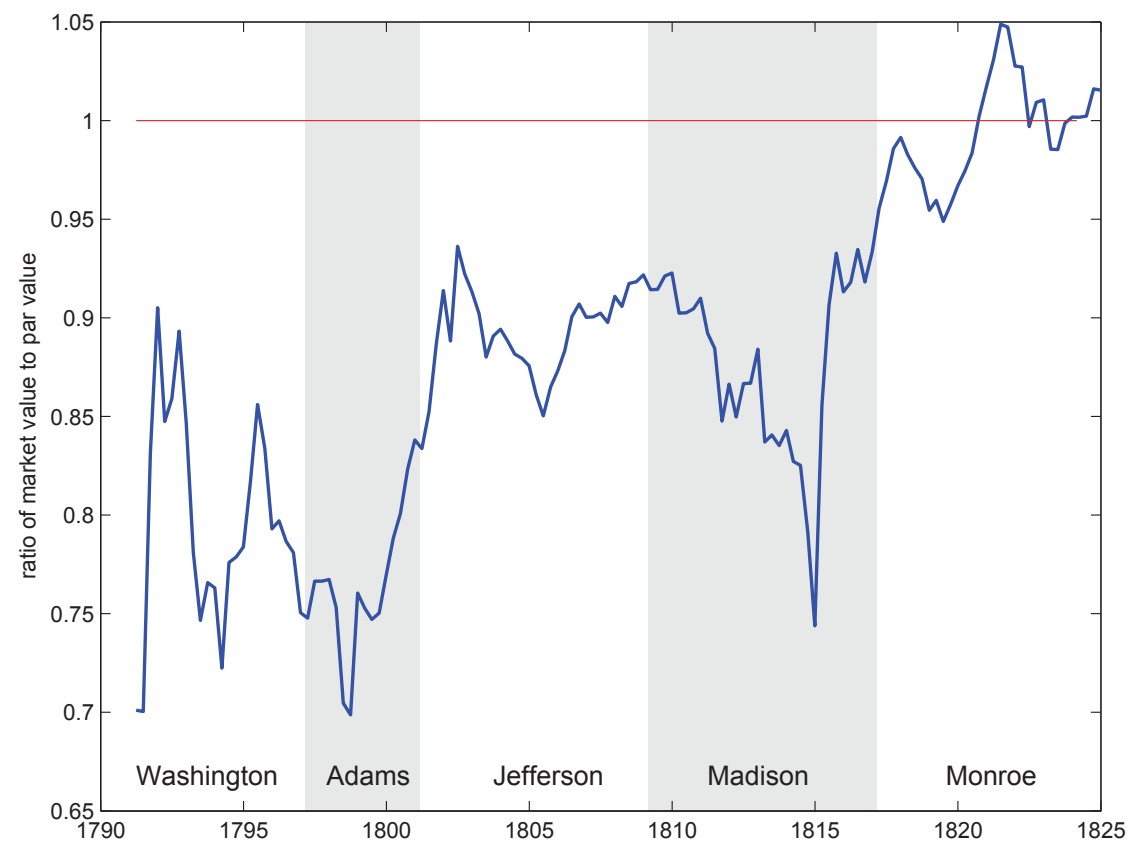

Figure 7: Ratio of the Market Value to the Par Value of the Outstanding Debt

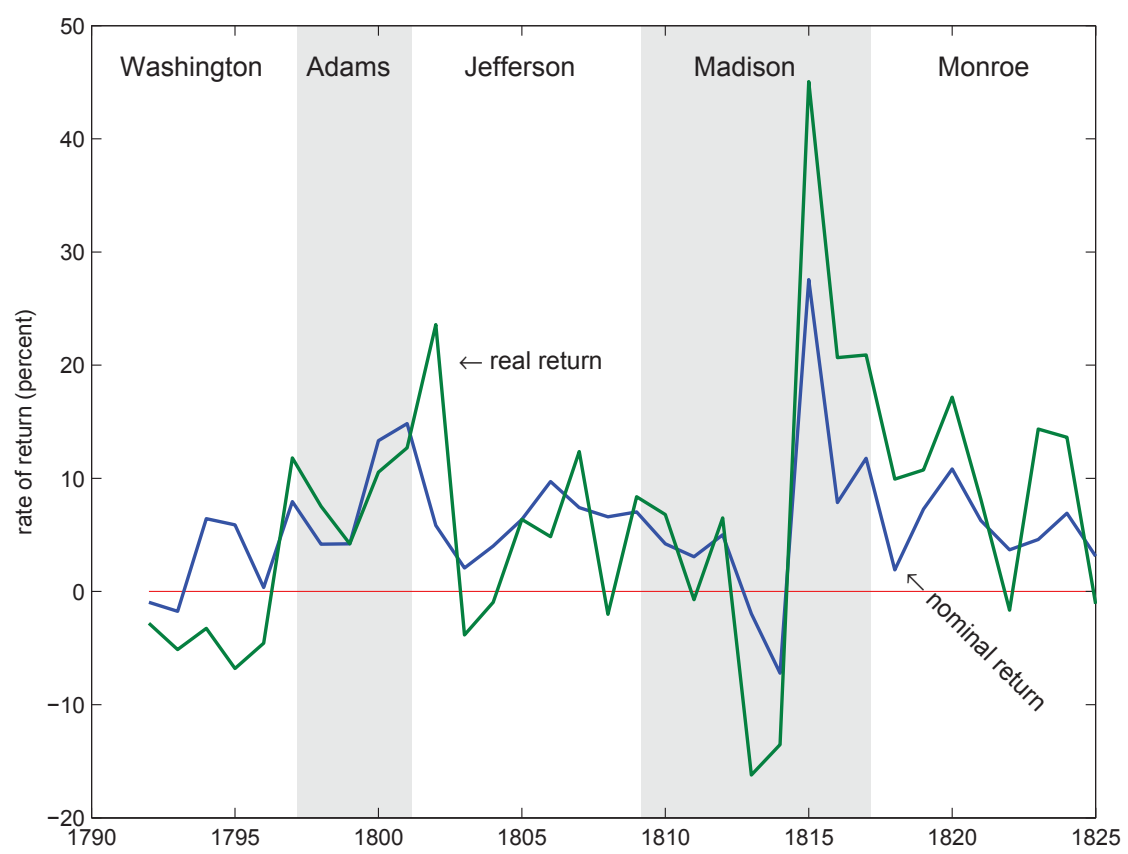

Figure 8: Real and Nominal Ex Post Holding Period Returns to Bondholders 


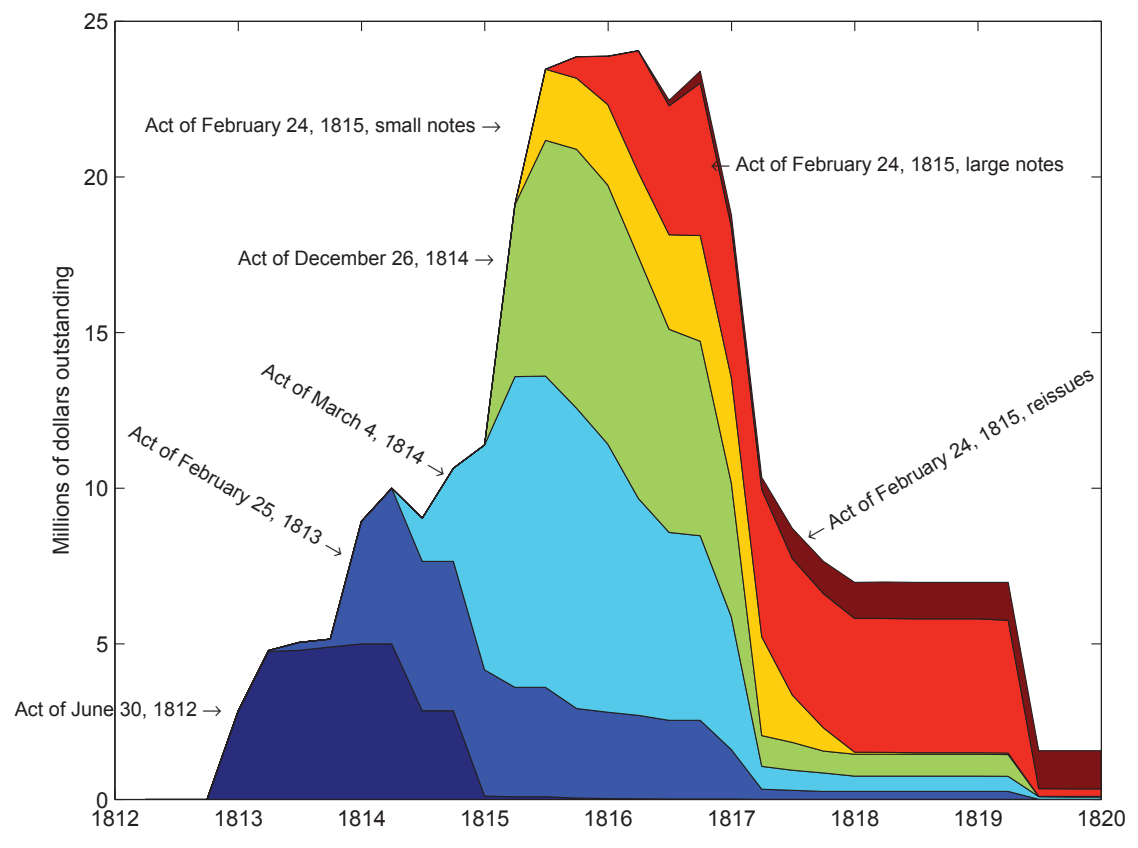

Figure 9: Treasury Notes Outstanding

Source: Bayley (1882).

were one-year loans and paid an interest rate of $5 \frac{2}{5}$ which corresponded to $1 \frac{1}{2}$ cents per day for every $\$ 100$ of principal. Ownership of Treasury notes was transferable, and the notes were accepted by the government for the payment of all duties and taxes, but they were not legal tender.

In figure 9 we plot the par value outstanding of each Treasury Note issue. Unlike the Revolutionary War period when nearly $\$ 25$ million Continentals had been issued in 1775 and 1776 alone, less than $\$ 25$ million in War of 1812 Treasury notes were outstanding at any moment. In spite of the high costs of issuing interest-bearing debt, Congress and the Treasury did not resort to inflationary finance.

Although they were not made legal tender, there is evidence that some of these Treasury Notes circulated as currency. ${ }^{25}$ For the first four issues, the minimum denomination was $\$ 100$. On February 25, 1815, the Congress issued smaller denomination notes: "Small Treasury Notes" bore no interest and were payable to the bearer with the intention that they circulate as a medium of exchange. These Small Treasury Notes bore denominations of $\$ 3, \$ 5, \$ 10, \$ 20$ and $\$ 50$. In contrast, "Large Treasury Notes" bore denominations of

\footnotetext{
${ }^{25}$ See Kagin (1984) for a more complete discussion of the demand Treasury notes.
} 


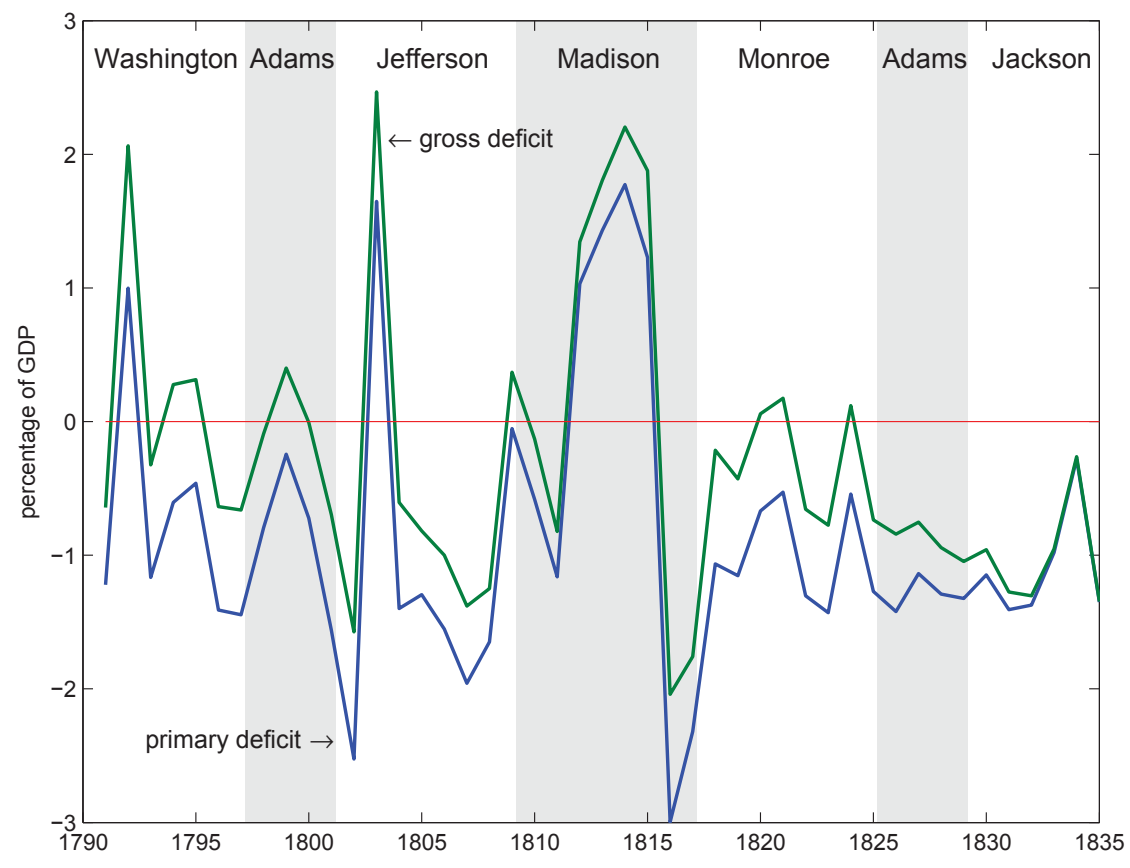

Figure 10: Federal Gross and Primary Deficits as a Share of GDP

Source: Calculated using data from U.S. Department of the Treasury (1890).

$\$ 100$ and upward, paid 5.4\% interest and, while they were transferable, they were payable to an assignee.

During the War of 1812, Treasury Notes held their value relative to contemporary long term loans, as well as relative to the Continental Dollars during the Revolutionary War and later the greenbacks during Civil War. Even at the lowest point in the war, December 1814 , Treasury Notes traded in New York City at around $\$ 93$ per $\$ 100$ par value, and by August 1815 their prices had risen to trade at par. ${ }^{26}$ In his December 1815 Annual Report, Secretary of the Treasury Alexander Dallas records that the Small Treasury Notes were sold at a premia ranging from $1 \frac{1}{4}$ to 4 percent. ${ }^{27}$ But the discredited Continental bills of credit still cast a dark shadow. By the following year, Dallas's successor, William Crawford described the need to issue Treasury Notes as an "embarrassment" and argued that the issuing of Treasury notes should be discontinued. ${ }^{28}$ Following the Secretary's advice, on March 3, 1817 Congress repealed all previous acts authorizing the issuing of Treasury Notes as well as the Secretary's authority to re-issue any existing notes.

\footnotetext{
${ }^{26}$ Prices are from the New York Price Current.

${ }^{27}$ See Dallas (1829, Appendix E, p. 52).

${ }^{28}$ See Crawford (1829, p. 75).
} 
In contrast to the post-Yorktown period, Federal revenues surged after the War of 1812 and the federal government ran substantial primary and gross surpluses for the next twenty years. See figure 10. Patterns in Federal revenues and expenditures around the War of 1812 resemble those prescribed by Gallatin. Consider the following 'back-of-the-envelop' calculation. Average annual expenditures from 1801 to 1811 were $\$ 8.7$ million; take this as the "annual expenses on the peace establishment and interest on the existing debt." The average annual expenditures from 1812 to 1816 were $\$ 30.1$ million per year, implying that the total cost of the war was roughly $5 \times(30.1-8.7)=\$ 110$ million.

Assuming a $6 \%$ interest rate, Gallatin's recommendation was to raise taxes by the annuity value of the interest costs, or $\frac{.06}{1+.06} \times 110=\$ 6.2$ million and borrow $110-6.2=$ $\$ 103.8$ million. In the Treasury accounts, annual tax revenue rose from an average $\$ 13.1$ million during the 1801 to 1811 period to $\$ 19.7$ million from 1812 to 1816: a difference of $\$ 6.6$ million. The quantity of debt outstanding rose $\$ 91.1$ million from $\$ 45.4$ million in March 1812 to $\$ 136.5$ million in September 1816. Given that the years from 1812 to 1815 were not favorable to public finance (e.g., the burning of Washington DC), the actual outcomes are remarkably close to policies recommended by the Gallatin-Barro model.

\section{A reputation restored}

Remnants of hard money Jackson Democrats had long regarded the Whig Party as soft on paper money. Remnants of the Whig Party formed the backbone of the Republican party. Did this history bequeath a credibility problem to the new Lincoln administration in March 1861? Maybe. But, anticipating an idea of Rogoff (1985) that a way to moderate a temptation to inflate is strategically to delegate monetary authority to an inflation hawk, Lincoln appointed as his Secretary of Treasury Salmon P. Chase, Governor of Ohio, formerly a Jackson hard money Democrat and a future Chief Justice of the U.S. Supreme Court. A decade later Chase would concur in a Supreme Court decision that declared unconstitutional Congress's 1862 action that awarded legal tender status to the paper money called greenbacks that he, as Secretary of Treasury, had issued to help pay for the war. The Congress had made them legal tender for all debts public and private, except payment of customs duties, the lion's share of Federal Revenues. The legal tender clause created many winners (debtors who owed dollars) and losers (creditors in dollars). ${ }^{29}$

\footnotetext{
${ }^{29}$ California and Oregon courts did not enforce the legal tender clause, so gold prevailed as the unit of account in those two states during the Civil War. California declined to accept greenbacks as payment for
} 


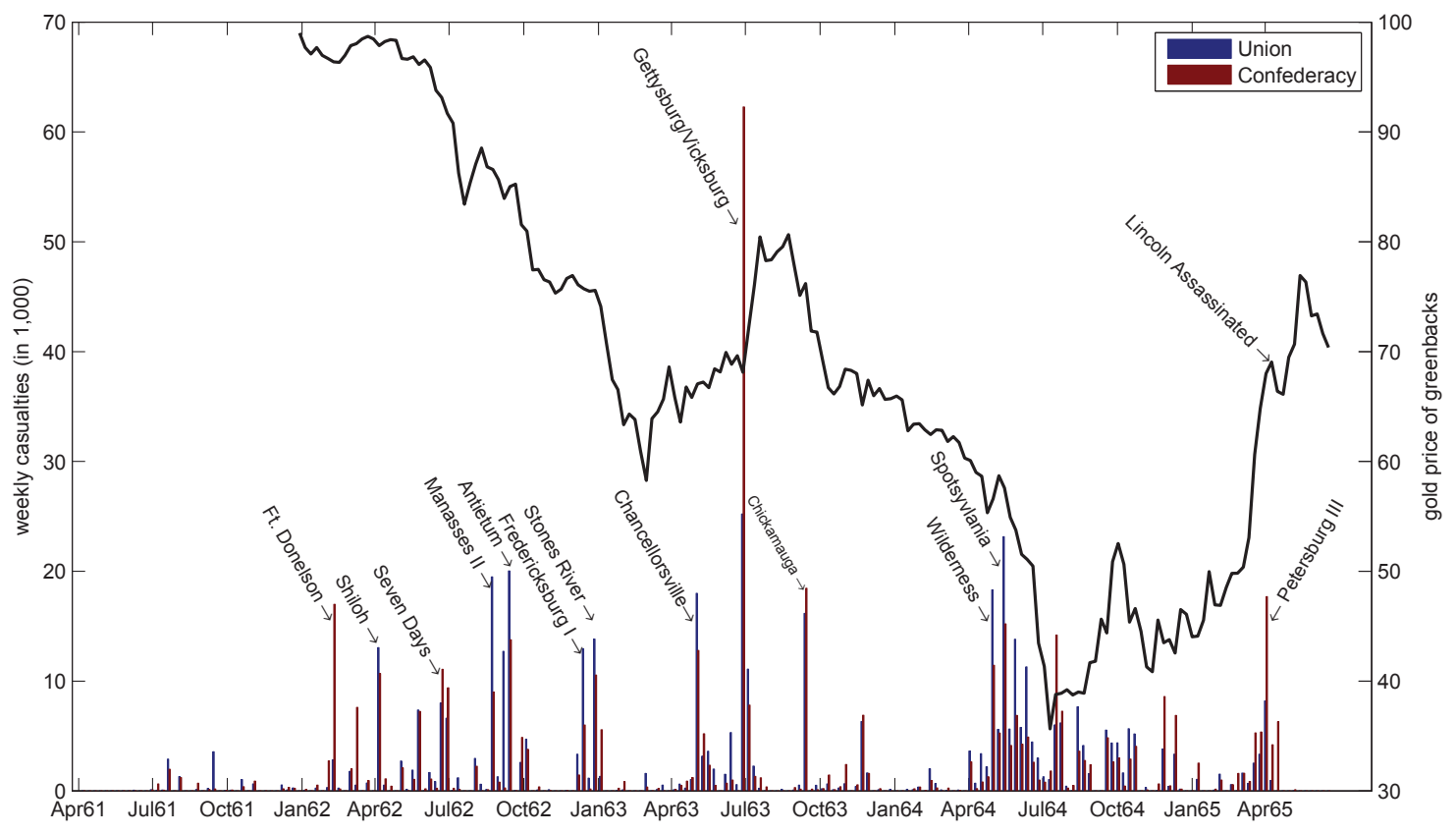

Figure 11: Gold Price of $\$ 100$ in Greenbacks and Weekly Union and Confederate Casualties Source: Prices are from Mitchell (1903). Casualties are from Greer (2005).

A market for exchanging gold dollars for greenbacks quickly emerged. As figure 11 illustrates, greenbacks traded at discounts whose depth varied inversely with victories of Union armies. ${ }^{30}$ After a string of Union defeats in the Spring of 1863, 60 gold dollars bought $\$ 100$ in greenbacks. The price rebounded to 80 after victories at Gettysburg and Vicksburg but fell again reaching its nadir in June 1864 at a price below 40 gold dollars. By the end of the war in 1865, 100 dollars in greenbacks was worth 50 or 60 dollars in gold. These discounts are substantially larger than the 8\% discounts War of 1812 Treasury Notes traded even at the lowest points of that war.

The expenditures of the war were unprecedented, generating budget deficits of nearly $10 \%$ of GDP. See figure 12 and compare the magnitudes of the Civil War deficits to the $2 \%$ of GDP deficits during the War of 1812 reported in figure 10. In response to the sudden increase in needed funds, Chase initially relied heavily on short-term borrowing. Much of this short-term debt was in the form of three-year '7-30s' - Treasury notes paying an interest rate of $7.3 \% .{ }^{31}$ While the Treasury imposed a host of new internal taxes including

state taxes. See Rothbard (2002).

${ }^{30}$ Also see McCandless (1996).

${ }^{31}$ Similar to the War of 1812 Treasury notes, the 7.3 percent interest rate was chosen since it made it 


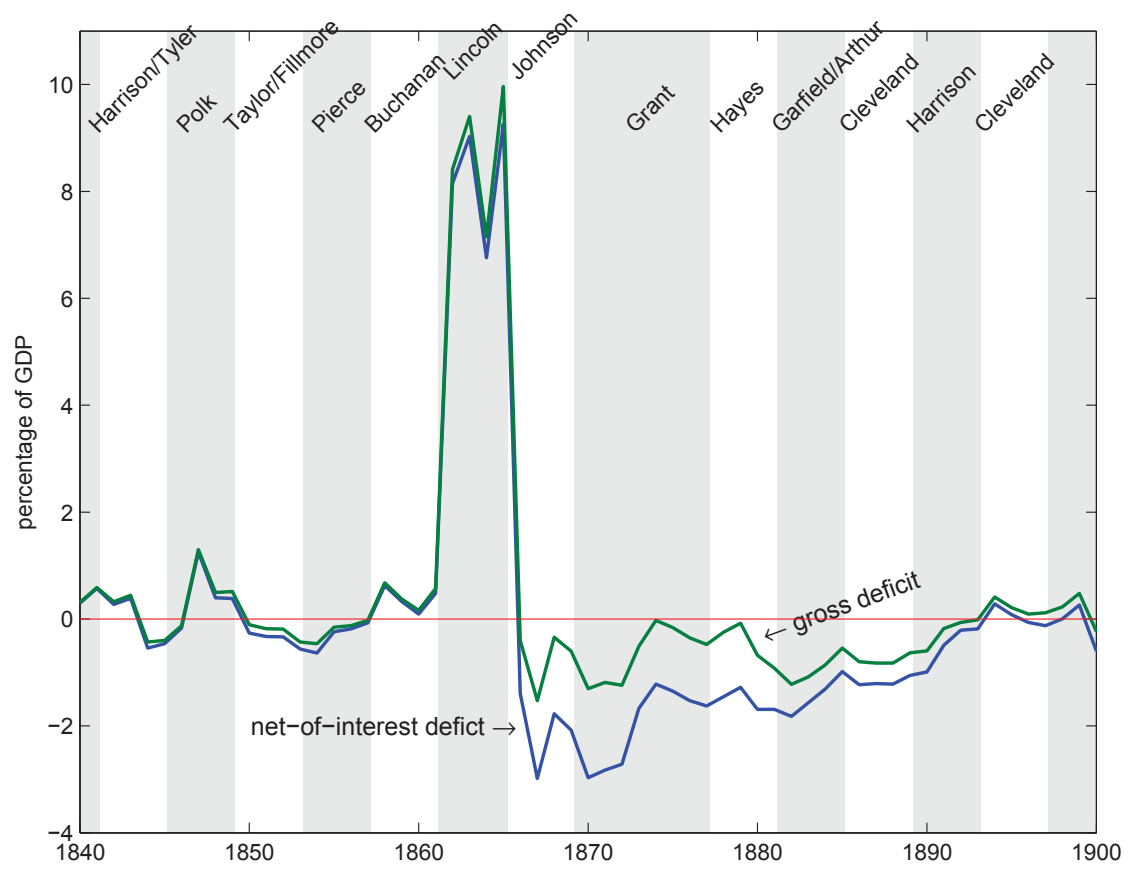

Figure 12: Federal Gross and Primary Deficits as a Share of GDP

Source: Calculated using data from Annual Reports of the Secretary of the Treasury.

the first federal income tax, taxes only accounted for $10 \%$ of expenditures in 1862 . During the war, for every $\$ 1$ the Union raised in taxes, it borrowed $\$ 3.59$.

To refinance these 7-30s into longer maturity securities, beginning in February 1862, the Congress authorized the Treasury to sell "5-20's", a bond redeemable in twenty years, but callable at par at the government's discretion in five years. (In effect, the Union government simultaneously borrowed and purchased a call option.) The 5-20's promised to pay interest in gold, but, in a masterpiece of ambiguity, were silent about whether the principal would be payable in greenbacks or in gold. ${ }^{32,33}$ The ambiguous legal status regarding which currency the principal of the 5-20's would be repaid was resolved by a political debate after the war. It mattered whether they would be paid in gold or in greenbacks because prices denominated in greenbacks doubled during the Civil War. But they receded enough from 1865 to 1879 that by 1879 the U.S. could resume specie payments, de facto making the greenbacks warehouse certificates for a set quantity of gold. But before the election of

easy to compute the nominal return: 2 cents per day for every $\$ 100$ in face value.

${ }^{32}$ Government policies are ambiguous when decision makers can't agree what to do now and decide to postpone decisions until a later time when they hope that they can agree.

${ }^{33}$ Despite the Congress's silence about whether the principal was payable in greenbacks or gold, Secretary Chase had advertised the loans would be repaid entirely in coin. 


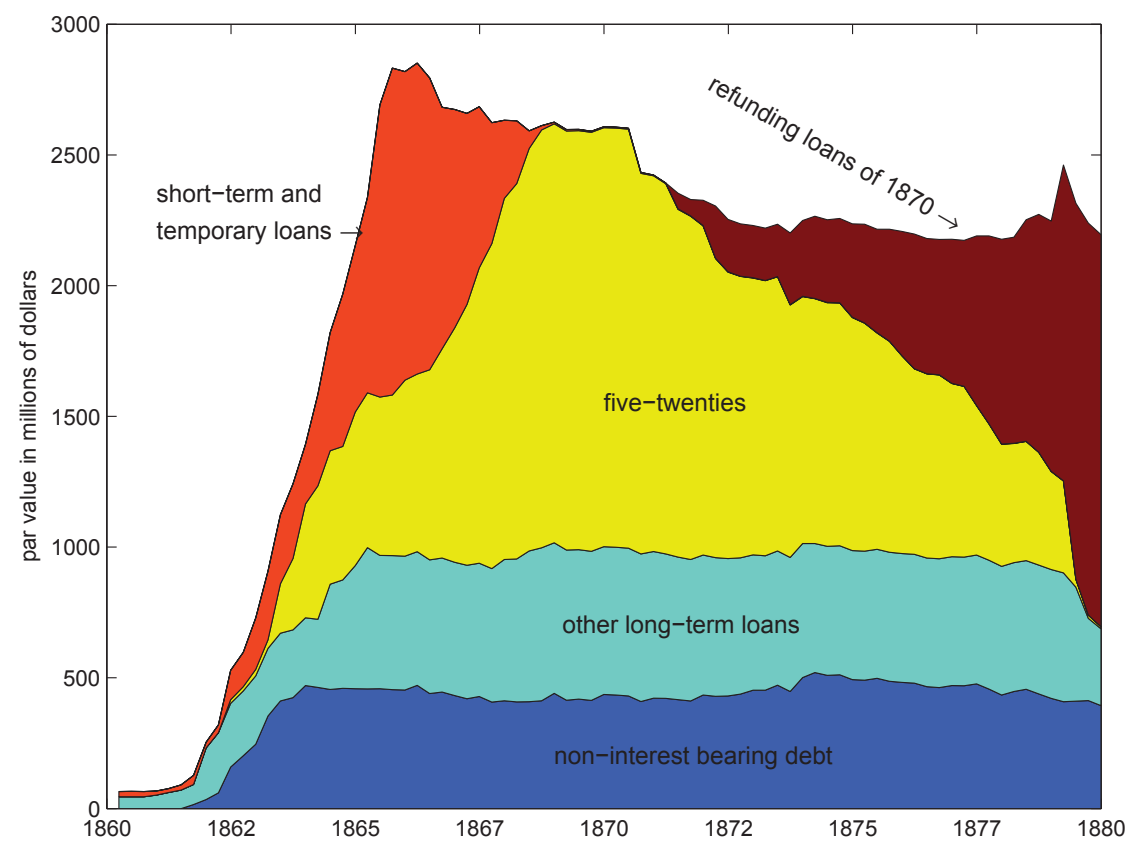

Figure 13: Debt by Type of Loan

President Grant in November 1868, there was widespread doubt and debate about whether the principal owed to owners of 5-20's was due in paper or in gold. In June 1868, the 5-20's comprised $70.5 \%$ of the interest bearing debt and gold was trading at a $40 \%$ premium. See figures 13 and 14.

The creation of the legal tender notes also created two types of debts: those promising to pay "lawful money" or greenbacks and those promising to pay "coin" or gold. ${ }^{34}$ See figure 15. At its peak in September 1865, debt promising the pay in 'lawful money' comprised over $54 \%$ of the outstanding debt. Up until 1862 the unit of account was specie and paper money sold 'at a discount.' However, from 1862 to 1879 prices for both goods and bonds (including those that promised to pay in coin) were quoted in 'lawful money' and gold dollars sold 'at a premium.'

\subsection{Why were the 5-20's issued?}

We interpret the government's decision to issue 5-20's in the first place as indicating policy makers' wish to implement policies that would promote lower future interest rates on government debt. Recall that the 5-20's had a par value of 100, promised 6 percent coupons

\footnotetext{
${ }^{34}$ We classify the $5-20$ s as payable in coin despite their ambiguous status.
} 


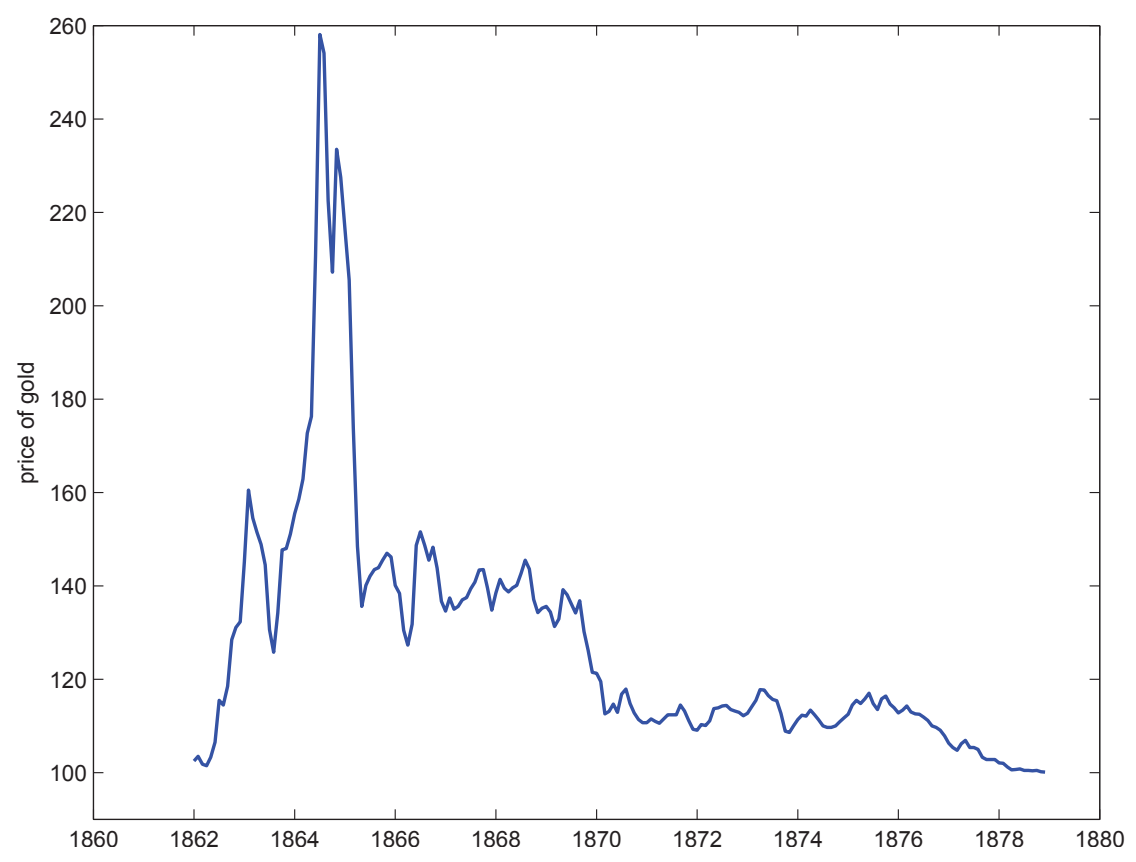

Figure 14: Price of Gold in Greenbacks

Source: Mitchell (1903)

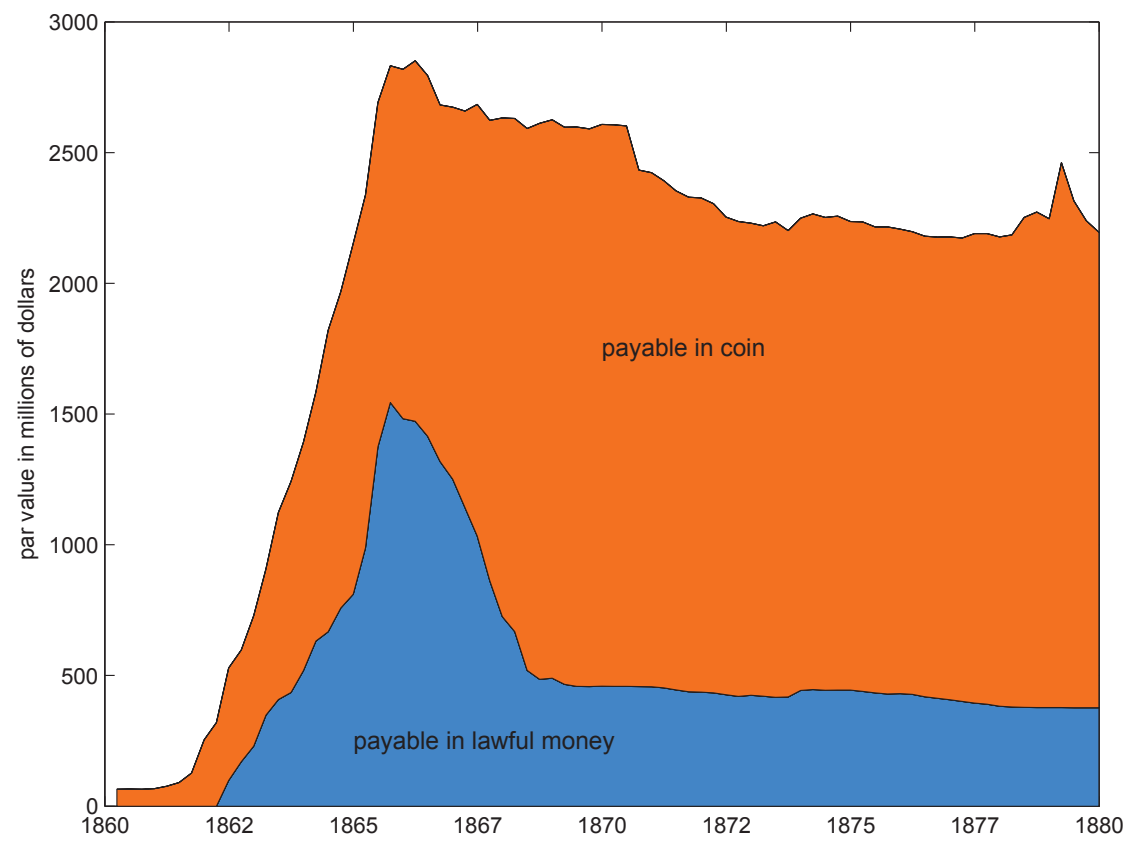

Figure 15: Debt Payable in Lawful Money and in Coin

Source: Bayley (1882) 
each year, matured after twenty years, and were callable at par at the governments' discretion after 5 years. Wanting to raise large amounts, why would the Union sell a bond that involved simultaneously purchasing a call option? Modigliani-Miller reasoning would tell us that whether it did or didn't was irrelevant. But the Congress and the Lincoln administration evidently didn't hold a Modigliani-Miller theory. ${ }^{35}$

To understand the government's decision to issue 5-20's, we think that it helps to posit heterogenous beliefs about future interest rates. ${ }^{36}$ If Union fiscal authorities imputed to the market different views about the likely future path of interest rates than theirs, then the call options associated with the 5-20's would have been a good buy for the Union government. Also, by buying a call option, the Union fiscal authorities could indicate to the market their intention to pursue continuation policies that would drive future interest rates lower than those forecast by the market, thereby rendering the call option more valuable than the market might have thought.

\subsection{Reducing interest rates on U.S. government debt}

Both sides of the late 1860s debate about whether to repay the principal on the 5-20's in paper or in gold could claim to advocate policies in the tradition of our first Secretary of Treasury. ${ }^{37}$ Hamilton (1790) had asserted that by restructuring the U.S. debt in his way, prospective interest rates on new issues of government debt would fall because default premiums would fall. But, by discriminating as he did, Hamilton had lowered interest rates in another sense, namely, by paying out substantially less to various classes of U.S. creditors than had originally been promised. The magic that Hamilton's restructuring plan promised was that it would save money for U.S. taxpayers by partially defaulting on some debts, while simultaneously promoting the prospect of lower default premiums on new and

\footnotetext{
${ }^{35}$ When the Mexican War broke out in 1846 , the credit of the U.S. government was so strong that the $6 \%$ bonds sold to finance the war were oversubscribed and quickly sold at a premium. Since these bonds were not callable with terms of ten and twenty years, the government repurchased these bonds above par as one use of the budget surpluses that materialized during the early 1850s. See Dewey $(1912$, p. 256).

${ }^{36}$ Harrison and Kreps (1978) showed that backing off of rational expectations just a little ignites interesting asset price dynamics. We read Newcomb (1865) as having had a heterogeneous beliefs model in mind when he criticized Union fiscal policy for rewarding traders who were pessimistic about Union prospects. A heterogeneous beliefs model in the Harrison and Kreps tradition also helps shed light on the argument of Alexander Hamilton (1790) that James Madison's discrimination scheme would reward those who had held pessimistic beliefs about US credit, while Hamilton wanted to reward those who had held optimistic views in order to influence beliefs of prospective US creditors.

${ }^{37}$ Newcomb (1865, p. 84) deplored the uncertainty that prevailed about how the Union would service its debt ("all is chance where all should be certainty".)
} 
future issues of U.S. government debt. That Hamilton had pursued that balancing act left room for advocates of very different debt management policies to claim that they were his true followers.

Thus, the Democrats and President Andrew Johnson meant one thing when they advocated reducing interest payments on the government debt, while the Republicans and Ulysses S. Grant meant something else. ${ }^{38}$ President Johnson emphasized the costs of high interest payments to current tax payers and advocated reducing those costs by paying principal in greenbacks.

Various plans have been proposed for the payment of the public debt. However they may have varied as to the time and mode in which it should be redeemed. There seems to be a general concurrence as to the propriety and justness of a reduction in the present rate of interest. ... The lessons of the past admonish the lender that it is not well to be over-anxious in exacting from the borrower rigid compliance to the letter of the bond. President Andrew Johnson (Fourth Annual Message December 9, 1868) 39

Against President Johnson, the Republicans advocated paying in gold. Defying Johnson, in 1868, both houses of Congress passed a bill affirming intentions to pay in specie unless otherwise stated, but President Andrew Johnson pocket vetoed it. This disagreement was presented to the voters in the fall of 1868 .

The third, fourth, and fifth planks of the Democratic Party platform of 1868 stated:

Third. Payment of the public debt of the United States as rapidly as practicable. All moneys drawn from the people by taxation, except so much as is requisite for the necessities of the government, economically administered, being honestly applied to such payment, and where the obligations of the government do not expressly state upon their face, or the law under which they were issued does not provide, that they shall be paid in coin, they ought, in right and in justice, to be paid in the lawful money of the United States.

Fourth. Equal taxation of every species of property, according to its real value, including government bonds and other public securities.

\footnotetext{
${ }^{38}$ Aligned with Johnson were debtors owing private claims denominated in greenbacks ('lawful money'). They well understood the implications for them of Ulysses S. Grant's policy that "Return to a specie basis can never be effected except by a shrinkage of values." See Brands (2012, ch. 69).

${ }^{39}$ Also see Dewey (1912, p. 346).
} 
Fifth. One currency for the government and the people, the laborer and the office-holder, the pensioner and the soldier, the producer and the bond-holder.

The fifth plank indicated eventual resumption of specie convertibility, but only after a period when the prevailing depreciation of the greenback could be exploited to reduce the ex post real returns awarded to holders of U.S. government bonds by repaying their principal in greenbacks, not gold.

The third plank of the Republican party platform of 1868 took a different position:

Third. We denounce all forms of repudiation as a national crime; and national honor requires the payment of the public indebtedness in the utmost good faith to all creditors at home and abroad, not only according to the letter, but the spirit of the laws under which it was contracted.

The voters elected the Republicans. Grant won the 1868 presidential election with 214 Electoral votes to Horatio Seymour's 80. The popular vote for Grant was 3,013,421 versus 2,706,829 for Seymour. In the Senate, the Republicans gained 5 seats extending their overwhelming majority to 62 to 12. Although the Democrats gained 20 seats in the House, partly because some Southern states had been readmitted into the Union since the election of 1866, the Republicans still held over 70 percent of House seats.

In his inaugural address, President Grant said that he would sign a bill committing the government to repay its debts in gold unless otherwise stipulated, like the bill that President Johnson had pocket vetoed:

A great debt has been contracted in securing to us and our posterity the Union. The payment of this, principal and interest, as well as the return to a specie basis as soon as it can be accomplished without material detriment to the debtor class or to the country at large, must be provided for. To protect the national honor, every dollar of Government indebtedness should be paid in gold, unless otherwise expressly stipulated in the contract. Let it be understood that no repudiator of one farthing of our public debt will be trusted in public place, and it will go far toward strengthening a credit which ought to be the best in the world, and will ultimately enable us to replace the debt with bonds bearing less interest than we now pay. U. S. Grant, first inaugural address, March 4, 1869. 
On cue, the 41st Congress's first act, passed on March 18, 1869, was titled 'An Act to Strengthen the Public Credit':

Be it enacted . . ., That in order to remove any doubt as to the purpose of the government to discharge all just obligations to the public creditors, and to settle conflicting questions and interpretations of the laws by virtue of which such obligations have been contracted, it is hereby provided and declared that the faith of the United States is solemnly pledged to the payment in coin or its equivalent of all the obligations of the United States not bearing interest, known as United States notes, and of all the interest-bearing obligations of the United States, except in cases where the law authorizing the issue of any such obligation has expressly provided that the same may be paid in lawful money or other currency than gold and silver. But none of said interest bearing obligations not already due shall be redeemed or paid before maturity unless at such time United States notes shall be convertible into coin at the option of the holder, or unless at such time bonds of the United States bearing a lower rate of interest than the bonds to be redeemed can be sold at par in coin. And the United States also solemnly pledges its faith to make provision at the earliest practicable period for the redemption of the United States notes in coin.

President Grant signed this Act into law. No Democrats voted to approve it.

\subsection{Grant gives no haircuts}

Committing the federal government to repay the 5-20s in gold resulted in large real returns to bondholders. From 1866 to 1875 the real holding period returns to federal government creditors averaged $10.2 \%$ per year. See figure 16 . Owners of the 5 -20s received an average real annual return of $11.7 \%$ over this period.

However in contrast to Hamilton's refinancing in 1790, the high returns delivered to federal bondholders did not come at the expense of holders of paper money. As figure 17 reveals, holders of non-interest bearing 'lawful money' - legal tender notes and fractional currency - saw the specie value of their assets appreciate through deflation. In June of 1868, it took 140 greenback to buy $\$ 100$ gold dollars. Five years later in 1873 , the price had fallen to 116.5. By the end of 1878, the two currencies traded at par. By 'closing the gap' between the two lines in this figure, the federal government assumed all of its promised obligations to holders of the greenbacks. Contrast this 'closing of the gap' to the persistent 


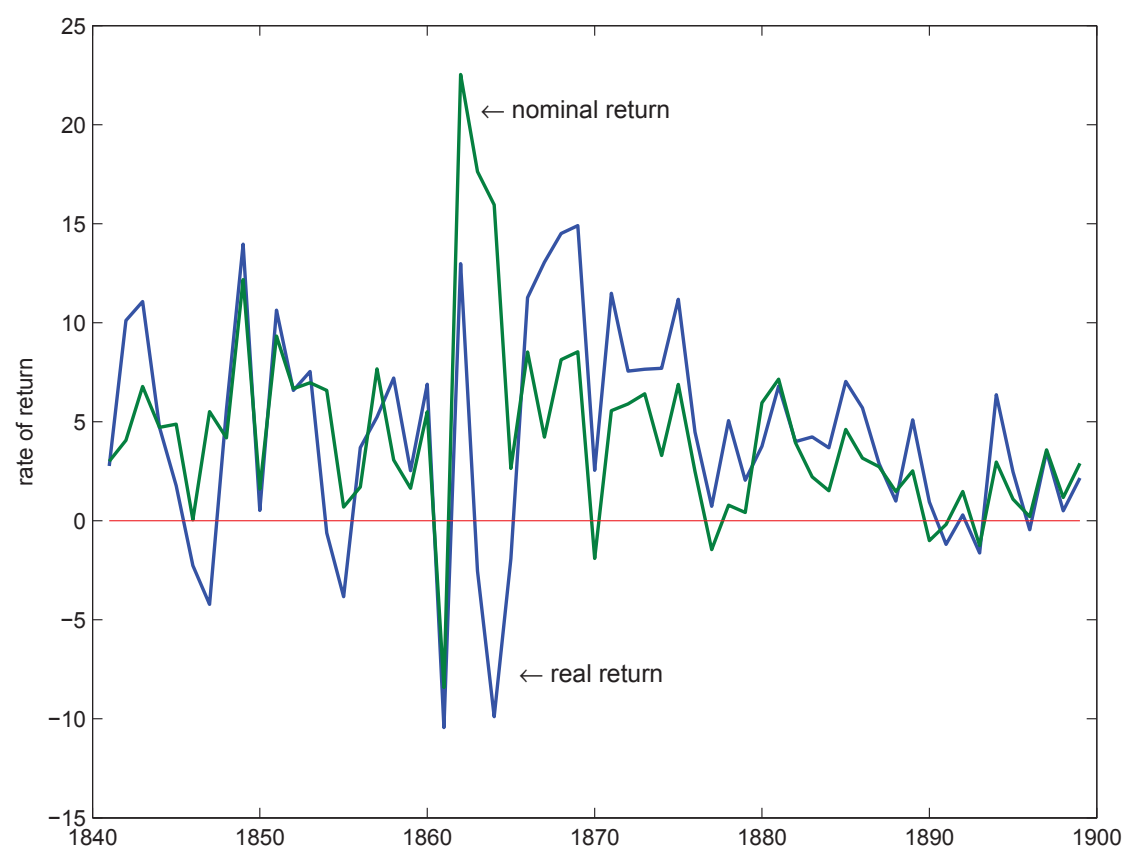

Figure 16: Real and Nominal Ex Post Holding Period Returns to Federal Bondholders Fiscal year. Valued Weighted.

gap between the market and par values of the debt observed in figure 4. Grant set the stage to redeem all the debt at par.

\section{Improvising implementation}

The 1869 Act to Strengthen the Public Credit set the U.S. on the road to resumption of convertibility of the greenback but was manifestly short of details about actions to achieve convertibility. The years from 1869 to 1900 witnessed a succession of Congressional and administrative actions that put the U.S. formally on a gold standard for 33 years, from 1900 to 1933 , and less formally before that from 1879 to 1900. The Congressional legislation and Treasury administrative decisions that ultimately produced these outcomes emerged fitfully from a sequence of agreements about fiscal policy that were often controversial because they seemed to render status quo U.S. fiscal and monetary policies unsustainable. Some of the important agreements along the road to the gold standard are:

1. On July 14, 1870 the Congress authorized new three bonds: a ten year bond paying a $5 \%$ coupon; a fifteen year bond paying a $4.5 \%$ coupon; and thirty year bond paying 


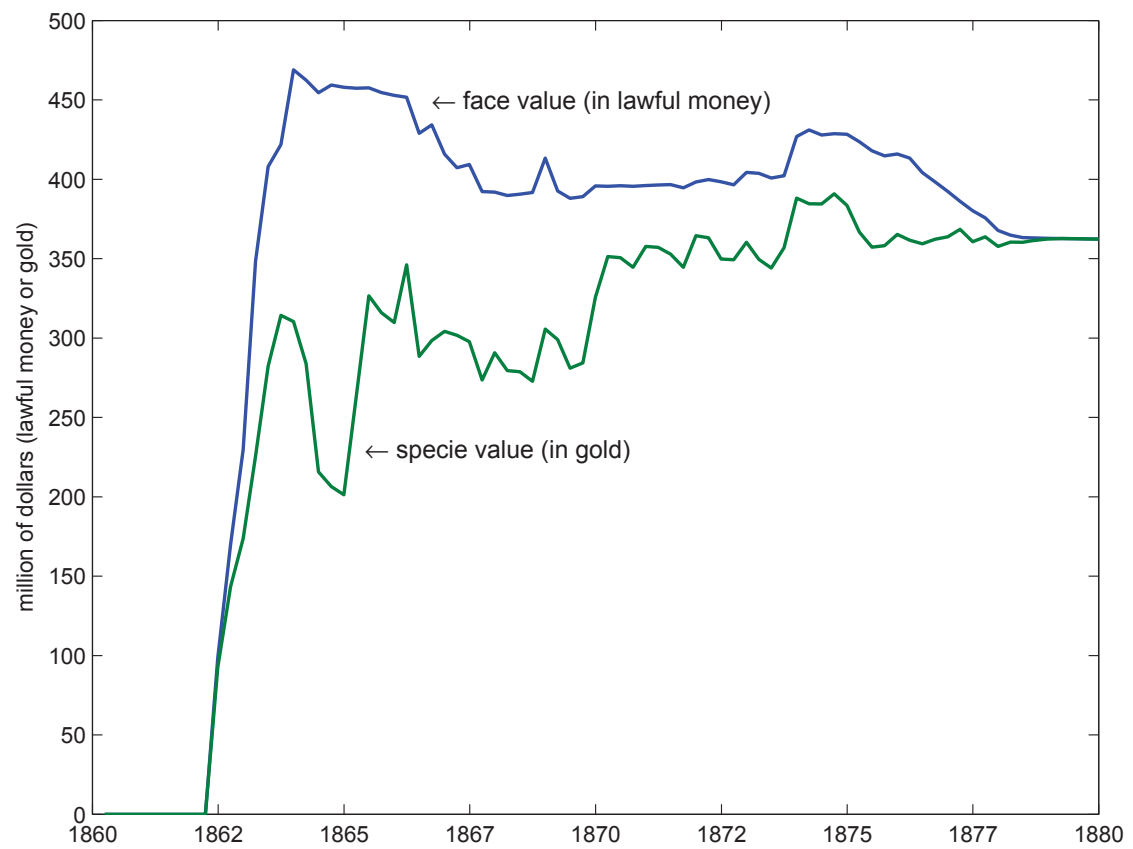

Figure 17: Face and Specie Value of Non-Interest Bearing Debt Payable in Lawful Money. Source: The face value is from Bayley (1882); the specie value is computed using the price of gold from Mitchell (1903). 
a $4 \%$ coupon. $^{40}$ Not only did this act state that the interest and principal on the new bonds were payable in gold; it also explicitly stated that the proceeds from these bonds were to be used to retire the 5-20's, purchasing them at par in gold - an intention realized during the years 1871 to 1879 as the Treasury exercised its option to call the 5-20s. See the 'refunding loans of 1870' in figure 13. These were first federal bond calls in U.S. history.

2. In the Coinage Act of 1873 that was later derided as 'the Crime of ' 73 ', Congress announced intentions eventually to make the greenback convertible into gold and not silver. It was silent about how that would be accomplished. But convertibility was ultimately achieved in 1879 .

3. In 1878 and 1890, respectively, the Bland-Allison and Sherman Acts required or authorized (more legislative ambiguity) the U.S. Treasury to purchase silver and to issue silver certificates called dollars. The legislation left open whether silver certificates were convertible into gold (another masterpiece of ambiguity). The Sherman Act delegated that decision to the Secretary of the Treasury. Successive secretaries did redeem them, but they could have chosen otherwise. It seems that sometimes the public believed that they would choose otherwise, setting off incipient runs on gold fought off by Grover Cleveland during his second term as president from 18931897. Substantial outstanding stocks of silver certificates contributed to a sequence of runs on gold in the 1890s, each of which was stemmed only when the U.S. Treasury borrowed gold to support the dollar.

4. The 1896 U.S. presidential election was contested mainly on Democratic candidate William Jennings Bryan's proposal that the U.S. freely coin silver at a ratio of 16/1 at a time when the market price ratio was about 30/1. Bryan lost. Gold discoveries and new technologies for extracting gold caused the price of gold to begin falling, taking the wind out of the sails of silver advocates.

5. In 1900, Congress passed the Gold Standard Act formally making U.S. dollars payable in gold.

6. During 1933, President Roosevelt issued several executive orders across several dates effectively taking the U.S. off the gold standard. On January 30, 1934 Congress passed

\footnotetext{
${ }^{40}$ The act was amended on January 20, 1871.
} 
the Gold Reserve Act. It repealed the gold clause. Those decisions were tested and upheld by the U.S. Supreme Court.

To us an interesting aspect of this story, which bears much more study, is how after a broad statement of good intentions (e.g., the 1869 Act to Strengthen the Public Credit), coherent policies emerged from a sequence of improvisations, political compromises, and administrative decisions. Ultimately, an intertemporal government budget constraint rendered policies coherent. During the dynamic democratic process leading to decisions, thoughtful ideas about how to smooth the transition from the greenback to gold as a unit of account were offered but discarded. For example, a House version of the 'Act to Strengthen the Public Credit' contained a section designed gradually reducing the proportion of contracts promising legal tender ('lawful money') by authorizing federal courts to enforce contracts written after a certain date and explicitly promising to pay gold. The section containing that proposal was dropped from the Act ultimately passed and signed by President Grant, but in a memorandum of June 1, 1874 that he circulated among some important government officials, President Grant endorsed the idea. ${ }^{41}$ It was not implemented.

\footnotetext{
${ }^{41}$ See Brands (2012, ch. 72) and Grant (2003, p. 114-117).
} 


\section{Concluding remarks}

If we were forced to conclude this paper with a provocative revisionist interpretation of U.S. government finance during three wars, it might be this. A conventional wisdom sees Alexander Hamilton as a paragon of financial responsibility who in 1790 promoted U.S. credit by executing an honorable and credit-enhancing rescheduling of debts incurred during the American Revolution. In doing that, Hamilton received little help from a less economically knowledgeable James Madison, who had advocated a misdirected discrimination scheme for tampering with pay outs to U.S. creditors, a scheme that would have permanently damaged U.S. credit. But if we judge Hamilton and Madison by the actions over which they presided, a different pictures emerges.

It was Hamilton who presided over massive discriminations and repudiations, though perhaps he repudiated less than had been expected during the 1780s, earning him substantial gratitude from 1780s speculators in some U.S. and state debts, but not in others (particularly purchasers of those forlorn Continentals). It was James Madison who during the War of 1812 presided over an administration that declined to make short-term U.S. debt a legal tender and, at the end the day, awarded positive returns to holders of short-term U.S. debt. ${ }^{42}$ The fact that the U.S. government refrained from using that mainstay of the American Revolution - an inflation tax -in financing the War of 1812, despite considerable difficulty in selling interest-bearing debt, established precedents which guided the way Ulysses S. Grant and the Republican party chose to complete Union policy for financing the Civil War. Late 1860s advocates of 'lowering ex post interest rates' to be paid to Union creditors might legitimately appeal to Alexander Hamilton as an example; but they could not appeal to the precedent set by the Madison administration and its successors.

Like all provocative revisionist histories, this one omits as much as it includes. The Madison administration faced different constraints and opportunities than did the WashingtonHamilton administration in 1790. The U.S. was bigger and wealthier in $1812 .{ }^{43}$ And as a result of how markets interpreted what Washington and Hamilton had done, the U.S. in 1812 faced reputations vis a vis its prospective creditors that differed from those that had confronted the new Washington administration in 1790.

\footnotetext{
${ }^{42}$ During the War of 1812, the Madison administration's commitment to honoring U.S. debt extended even to British creditors. See Trotter (1839, p. 5).

${ }^{43}$ Estimates of population stand at 3.9 million in 1790 and 7.4 million in 1811. Estimates of real GDP stand at 4 billion 2005 dollars in 1790 and 11 billion in 1811.
} 


\section{References}

Adams, Henry. 1891a. The Bank of England Restriction. In Historical Essays, 178-236. New York: Charles Scriber's and Sons.

- 1891b. The Legal Tender Act. In Historical Essays, 279-317. New York: Charles Scriber's and Sons.

Aiyagari, S. Rao, Albert Marcet, Thomas J. Sargent, and Juha Seppala. 2002. Optimal Taxation without State-Contingent Debt. Journal of Political Economy 110 (6):12201254 .

Atkeson, Andrew. 1991. International Lending with Moral Hazard and Risk of Repudiation. Econometrica 59 (4):1069-89.

Bancroft, George. 1886. A plea for the Constitution of the U.S. of America: Wounded in the house of its Guardians. New York: Harper and Brothers.

Barro, Robert J. 1979. On the Determination of the Public Debt. Journal of Political Economy 87 (5):940-71.

Bayley, Rafael. 1882. The National Loans of the United States from July 4, 1776 to June 30, 1880. Washington DC: Government Printing Office, second ed.

Brands, H. W. 2012. The Man Who Saved the Union: Ulysses S. Grant in War and Peace. New York: Doubleday.

Bryant, John and Neil Wallace. 1984. A Price Discrimination Analysis of Monetary Policy. The Review of Economic Studies 51 (2):279-288.

Bullock, Charles. 1895. The Finances of the United States from 1775 to 1789, With Especial Reference to the Budget. Madison, WI: University of Wisconsin Press.

Chamley, Christophe and Herakles Polemarchakis. 1984. Assets, General Equilibrium and the Neutrality of Money. Review of Economic Studies 51 (1):129-38.

Chari, V. V., Lawrence J. Christiano, and Patrick J. Kehoe. 1994. Optimal Fiscal Policy in a Business Cycle Model. Journal of Political Economy 102 (4):617-52. 
Crawford, William. 1829. Report on the Finances: December, 1816. Reports of the Secretary of the Treasury of the United States Vol 2.

Dallas, Alexander. 1829. Report on the Finances: December, 1815. Reports of the Secretary of the Treasury of the United States Vol 2.

Dewey, Davis R. 1912. Financial History of the United States, 4th edition. New York: Longmans, Green, and Company.

Elliot, Jonathan. 1845. The Funding System of the United States and of Great Britain With Some Tabular Facts of Other Nations Touching the Same Subject. Washington DC: United States House of Representatives (28th, 1st session).

Ferguson, E. James. 1961. The Power of the Purse: A History of American Public Finance, 1776-1790. Chapel Hill, NC: The University of North Carolina Press.

Fetter, Frank Whitson. 1950. Legal Tender during the English and Irish Bank Restrictions. Journal of Political Economy 58 (3):241-253.

Fudenberg, Drew and David M Kreps. 1987. Reputation in the Simultaneous Play of Multiple Opponents. Review of Economic Studies 54 (4):541-68.

Gallatin, Albert. 1837. Report on the Finances November, 1807. Reports of the Secretary of the Treasury of the United States Vol 1.

Garber, Peter. 1991. Alexander Hamilton's Market Based Debt Reduction Plan. CarnegieRochester Conference Series on Public Policy 35:79-104.

Grant, Ulysses S. 2003. The Papers of Ulysses S. Grant: 1874. Carbondale, IL: Southern Illinois University Press, ed. John Y. Simon, Vol. 25.

Greer, Darrach. 2005. Counting Civil War Casualties, Week-ByWeek, For The Abraham Lincoln Presidential Library and Museum. http://www.brcweb.com/alplm/BRC_Counting_Casualties.pdf .

Grubb, Farley. 2008. The Continental Dollar: What Happened to it After 1779? NBER Working Paper 13770 .

- 2011. State Redemption of the Continental Dollar, 1779-1790. NBER Working Paper 17209 . 
Hall, George J. and Thomas J. Sargent. 2012. U.S. Fiscal Accounting and Debt Management Prior to and Including the Funding Act of August 4, 1790. manuscript .

Hamilton, Alexander. 1790. Report on Public Credit. Presented to Congress on January 9, 1790.

Harrison, J Michael and David M Kreps. 1978. Speculative Investor Behavior in a Stock Market with Heterogeneous Expectations. The Quarterly Journal of Economics $92(2): 323-36$.

Howe, Daniel Walker. 2007. What Hath God Wrought: The Transformation of America, 1815-1848. New York: Oxford University Press.

Jones, Larry E., Rodolfo E. Manuelli, and Peter E. Rossi. 1997. On the Optimal Taxation of Capital Income. Journal of Economic Theory 73 (1):93-117.

Kagin, Donald. 1984. Monetary Aspects of the Treasury Notes of the War of 1812. Journal of Economic History 44 (1):69-88.

Kydland, Finn E. and Edward C. Prescott. 1977. Rules Rather Than Discretion: The Inconsistency of Optimal Plans. Journal of Political Economy 85 (3):473-91.

Lucas, Robert E. Jr. and Nancy L. Stokey. 1983. Optimal fiscal and monetary policy in an economy without capital. Journal of Monetary Economics 12 (1):55-93.

Lucas, Robert Jr. 1986. Principles of fiscal and monetary policy. Journal of Monetary Economics 17 (1):117-134.

McCandless, George. 1996. Money Expectations, and the U.S. Civil War. American Economic Review .

Mitchell, Wesley. 1903. A History of the Greenbacks: With Special Reference to the Economic Consequences of Their Issue: 1862-65. Chicago, IL: University of Chicago Press.

Newcomb, Simon. 1865. A Critical Examination of our Fiscal Policy During the Southern Rebellion. New York: D. Appleton and Company.

Peled, Dan. 1985. Stochastic inflation and government provision of indexed bonds. Journal of Monetary Economics 15 (3):291-308. 
Phelan, Christopher and Robert M Townsend. 1991. Computing Multi-period, InformationConstrained Optima. Review of Economic Studies 58 (5):853-81.

Rogoff, Kenneth. 1985. The Optimal Degree of Commitment to an Intermediate Monetary Target. The Quarterly Journal of Economics 100 (4):1169-89.

Rothbard, Murray N. 2002. A History of Money and Banking in the United States: the Colonial Era to World War II. Auburn, Alabama: Ludwig von Mises Institute.

Sargent, Thomas J. 1987. Dynamic Macroeconomic Theory. Cambridge, Massachusetts: Harvard University Press.

- 2006. Ambiguity in American monetary and fiscal policy. Japan and the World Economy 18 (3):324-330.

Silber, William L. 2008. When Washington Shut Down Wall Street: The Great Financial Crisis of 1914 and the Origins of America's Monetary Supremacy. Princeton, New Jersey: Princeton University Press.

Sims, Christopher A. 2001. Fiscal Consequences for Mexico of Adopting the Dollar. Journal of Money, Credit and Banking 33 (2):597-616.

Sleet, Christopher. 2004. Optimal Taxation with Private Government Information. Review of Economic Studies 71 (4):1217-1239.

Sleet, Christopher and Sevin Yeltekin. 2006. Optimal taxation with endogenously incomplete debt markets. Journal of Economic Theory 127:3673.

Sylla, Richard E., Jack Wilson, and Robert E. Wright. 2006. Early U.S. Security Prices. http://eh.net/databases/early-us-securities-prices .

Thomas, Jonathan and Tim Worrall. 1990. Income fluctuation and asymmetric information: An example of a repeated principal-agent problem. Journal of Economic Theory $51(2): 367-390$.

Tobin, James. 1961. Money, Capital and Other Stores of Value. American Economic Review 51 (2):26-37. 
Trotter, Alexander. 1839. Observations on the Financial Position and Credit of Such of the States of the North American Union as Have Contracted Public Debts. London: Longman, Orme, Brown, Green, and Longmans.

U.S. Department of the Treasury. 1890. Annual Report of the Secretary of the Treasury on the State of the Finances. Washington, D.C.

Wallace, Neil. 1981. A Modigliani-Miller Theorem for Open-Market Operations. American Economic Review 71 (3):267-74. 